\title{
How Do Pensions Affect Corporate Capital Structure Decisions?
}

\author{
Anil Shivdasani \\ Kenan-Flagler Business School \\ University of North Carolina at Chapel Hill \\ Chapel Hill, NC 27599 \\ (919) 962-6124 \\ Anil.Shivdasani@Unc.edu \\ Irina Stefanescu* \\ Kelly School of Business \\ Indiana University \\ 1309 East $10^{\text {th }}$ Street, Rm 370 \\ Bloomington, IN 47405 \\ stefanei@indiana.edu
}

June 2009

\begin{abstract}
This paper examines the capital structure implications of defined benefit corporate pension plans. The magnitude of the liabilities arising from these pension plans is substantial. We show that leverage ratios for firms with pension plans are about 35\% higher when pension assets and liabilities are incorporated into the capital structure. We estimate that the tax shields from pension contributions are about a third of those from interest payments. Pension contributions have a modest effect in lowering firms' marginal corporate tax rates. Once pensions are considered, firms are less conservative in their choice of leverage than has been previously thought. We show that firms incorporate the magnitude of their pension assets and liabilities into their capital structure decisions.
\end{abstract}

Keywords: Pension Plans; Debt; Capital Structure; Marginal Tax Rates

JEL classification: G32; H20; J33

Address Correspondence to Anil Shivdasani

We thank Nina Baranchuk, Jennifer Conrad, Paolo Fulghieri, Eitan Goldman, David Guilkey, Matthias Kahl, Wayne Landsman, Ron Masulis, Mitchell Petersen, Jorg Rocholl, James Schallheim, Merih Sevilir, Doug Shackelford, Sheri Tice, Josef Zechner, seminar participants at Bocconi, William and Mary, HEC Paris, Indiana, Norwegian School of Economics, Tilburg, North Carolina, Vanderbilt, Virginia Tech, Michigan, Washington, the 2005 European Finance meeting, the 2005 FMA conference, the 2006 Batten Conference, the 2006 Western Finance Association meeting, and the 2009 FIRS meetings. We are especially thankful to John Graham for his detailed suggestions and assistance with the simulation of marginal tax rates. We thank Ari Jacobs (formerly Head of Pension Benefits Advisory Group at Citigroup), Mark Marinello (formerly Manager of Financial Operations at IBM), Jay Vivian (IBM Retirement Fund), and Joseph Krettek (Pension Benefit Guarantee Corporation) for helpful discussions. 
“' 'Investing in our pension as long as we get the tax deduction for it is a very good investment for us,' Harry Stonecipher, president and chief executive officer of Boeing, told analysts in a third quarter conference call in October. Boeing's \$3.6 billion contribution in 2004 will result in a tax benefit that year of between $\$ 1.1$ billion and $\$ 1.3$ billion, assuming a tax rate of 30\% to 35\%, according to Boeing spokesman John Dern.”

Wall Street Journal (2005), "How companies make the most on pensions"

\section{Introduction}

The bulk of capital structure research has focused on explaining the leverage choice as it is reported on the balance sheet. Yet companies have sizeable assets and liabilities that do not appear anywhere on the balance sheet, many of which are recorded in complex ways that obscures their economic reality. Perhaps nowhere is this distinction between on and off balance sheet items more relevant than when it comes to corporate pension plans. The aggregate value of defined benefit pension assets for US corporations is estimated at \$2.2 trillion, an amount far greater than that of any other off-balance sheet item. ${ }^{1}$

With a few exceptions, the capital structure implications of corporate pension plans have been largely unexplored. Little attention has been paid to how recognizing pension assets and liabilities changes our measurement of corporate leverage and the impact of this measurement issue on tests of corporate capital structure. The importance of pension contributions as a source of tax shields and their effect on companies' marginal tax rates is largely unknown despite the central role that marginal tax rates play in corporate finance. We also do not understand how companies treat pension liabilities as a substitute for debt financing and the degree to which the observed capital structures of companies vary systematically according to the pension exposures faced by companies. We explore these issues in this paper.

We study all publicly traded firms on Compustat from 1991 to 2003. About a fourth of these firms have defined benefit pension plans where the pension liabilities are long term binding obligations and share many characteristics of financial debt. For example, contributions to pension plans are taxdeductible, much like interest expense on debt and failure to make mandatory contributions on the pension plans can trigger bankruptcy. For some companies, the magnitude of pension assets and liabilities is substantial. On average, pension plan assets are $16.4 \%$ of the book value of assets recorded on the balance sheet and represent $62 \%$ of the market value of the firm's equity though there is considerable variation across firms.

We examine the importance of pension assets and liabilities in the context of the overall capital structure of the firm. Though they reside in a separate legal trust, the assets and liabilities belong to the firm which is responsible for any shortfalls between promised benefits and the assets set aside to cover these benefits. As we elaborate below however, the economic impact of the pension plan depends on the

\footnotetext{
${ }^{1}$ Source: Watson Wyatt, 2006 estimates.
} 
total size of the plan and not just the degree by which a plan is under or overfunded at a particular point in time. Hence, we treat the pension plan as a fully owned subsidiary of the firm and calculate consolidated (pension and financial debt) leverage ratios. Our treatment of pension plans as fully-owned subsidiaries is consistent with findings in several studies that show that pension plan assets and liabilities are valued by the securities markets as corporate assets and liabilities. We show that the difference in balance sheet leverage ratios and consolidated leverage ratios is substantial. For Compustat firms with defined benefit plans, both book and market leverage are about one-third larger when calculated on a consolidated basis: average book leverage increases from $25 \%$ to $34 \%$, while market leverage increases from $20 \%$ to $27 \%$.

Taxes play a central role in corporate financing decisions and accurate measurement of the marginal tax rate is of importance in capital structure tests. Since pension contributions are tax deductible, they can be an important source of tax savings and in turn can affect the marginal tax rate a company faces in its debt financing decisions. In our sample, pension contributions amount on average, to $56 \%$ of the total interest expense reported by firms though the distribution is skewed by some very large pension plans. The large size of some pension contributions implies that they have the potential to impact companies' marginal tax rate for debt financing. To evaluate the effect of pension contributions on tax shields, we conduct a detailed calculation of corporate marginal tax rates that includes the effects of pension contributions. With the recalculated marginal tax rates, we estimate the tax benefits of consolidated leverage are $31 \%$ higher than the tax benefits of financial debt alone. The tax savings from pension contributions account for $1.5 \%$ of the market value of the firm, on average. Importantly, we demonstrate that the existence of a pension plan significantly lowers the extent to which firms can afford to take on additional leverage from a tax perspective.

According to the tradeoff theory of capital structure, firms balance the benefits of debt such as those arising from tax shields against the costs of debt. Since pension contributions provide an important source of tax savings and potentially lower the tax advantages from debt financing, we should expect lower leverage ratios for firms with pension plans, all else equal. This is exactly what we observe. In a treatment effects model that incorporates the self-selectivity of pension plans and the endogeneity of pension liabilities, we estimate that a 1 percentage point increase in the pension liability to total assets ratio is associated with a 0.36 percentage point decrease in the debt to total assets ratio. This suggests that managers partially substitute pension-related deductions for interest deductions in capital structure decisions. However, the substitution effect between pensions and financial debt is not perfect, and we discuss several reasons for this partial substitution effect.

As an alternative to the treatment effects approach, we estimate the relation between pension liabilities and financial debt in a firm-fixed effects framework. Lemmon, Roberts, and Zender (2008) describe how coefficient estimates of most traditional determinants of capital structure drop considerably in fixed- 
effects models because most of the variability in capital structure appears to be time invariant. We show that pension liabilities remain a highly significant determinant of capital structure in a firm fixed-effects model. A variance decomposition of leverage also suggests that pension liabilities are an element of the time-invariant factors shown to be very important by Lemmon et. al (2008).

Given the substitution between pensions and financial debt, we examine whether corporate pension plans help explain why firms appear to be underleveraged from a tax perspective. Graham (2000) shows that most firms are very conservative in their capital structure choice in that they operate on the flat segment of their tax benefit functions and far from the point where marginal tax benefit from debt starts declining (the "kink" in Graham's terminology). This perceived inefficiency of capital structure from a tax perspective is particularly surprising, since taxes are "important" or "very important" to most of the CFOs surveyed by Graham and Harvey (2001).

Using the distance of the kink from one as a measure of debt conservatism, we find that debt conservatism shrinks considerably in our framework. By our estimates, the gap between optimal leverage from a tax perspective and observed leverage shrinks by about one-third when pension plans are included, indicating that firms are less conservative in their capital structure decisions than has been previously thought. Further, the results offer an explanation for why capital structure seems most inefficient for large and profitable companies. For example, Graham (2000) notes that "the firms that use debt conservatively are large, profitable, liquid, in stable industries", and face low ex ante costs of distress. As we show, these characteristics are precisely the attributes of firms that have defined benefit plans, suggesting that the tax benefits of pension plans are at least one component of the explanation to the capital structure puzzle.

Our analysis contributes to at least four strands of literature. First, our results add to a recent literature illustrating the interdependence between various aspects of corporate financial policy and corporate pension plans. Petersen (1994) shows that defined contribution pension plans allow firms to vary contributions according to their cash flows, enabling them to lower their operating leverage. Rauh (2006a) shows how pension contributions can lead to financial constraints and affect the level of corporate investment. Frank (2002) finds a positive relationship between defined benefit plan asset allocation and the firms' tax benefits. Jin, Merton and Bodie (2006) find that investors recognize pension assets and liabilities and incorporate them in determining the cost of equity capital for these firms.

Second, our paper adds the evidence on the role of taxes in corporate pension policy. Thomas (1988) finds that pension contributions are positively correlated with the sponsor's tax status and that firms with a low tax status are less likely to adopt defined benefit plans. Petersen (1992) shows that the decision to terminate a pension plan is driven partly by taxes, as terminations typically coincide with low tax years. Both papers emphasize an important role for taxes in the management of corporate pension plans. 
Third, our results complement the literature on how off-balance sheet financing activities are affected by corporate tax considerations. Graham, Lemmon, and Schallheim (1998) study operating leases that are also not recorded on the balance sheet. They find that firms with lower tax rates employ operating leases more extensively, suggesting that tax shields are being transferred between the lessor and leesee. While leases are undoubtedly a very important source of off-balance sheet financing, pension obligations are typically of much larger magnitude. For example, at the beginning of 2005, off-balance sheet pension liabilities for S\&P 500 firms stood at $\$ 1.26$ trillion, compared to operating leases of $\$ 395$ billion. $^{2}$ In related work, Graham and Tucker (2006) show that questionable tax shelters provide sizeable corporate tax deductions and firms tend to use less financial leverage when these shelters are in place. They note that these firms do not appear to be underlevered once their deductions from shelters are considered.

Finally, our findings add to a growing list of explanations for why companies appear to adopt seeming inefficient capital structures in light of the substantial tax benefits of debt. Faulkender and Petersen (2006) highlight the role of supply side constraints faced by lenders and Molina (2005) and Almeida and Philipon (2007) note the importance of measuring the ex ante probability of distress and credit spreads. MacKie-Mason (1990) shows that depreciation and tax credits explain cross-sectional variation in capital structure and Schallheim and Wells (2006) find that they help explain why firms adopt conservative debt policies. Graham, Lang, and Shackelford (2004) show that tax deductions for employee stock options explain why high growth companies in the NASDAQ 100 use little debt. However, option deductions do not explain debt conservatism among S\&P 100 firms that comprise mainly of lower-growth firms in traditional and stable industries. Since companies with pension plans fall exactly into this latter category, i.e. large and profitable companies in mature industries, our findings complement Graham, Lang, and Shackelford and provide an explanation why these companies appear substantially underleveraged. In this regard, our evidence points to corporate pensions as being one of the missing links in the capital structure debate.

The paper is organized as follows. Section 2 describes the features of pension plans. Section 3 discusses the role of pension plans in capital structure decisions. Section 4 describes the data used in the paper and section 5 details our refinement of marginal tax rates and estimates the tax benefits of pension plans. Section 6 examines the effect of pension liabilities on corporate financial policy. Section 7 reports robustness tests and section 8 concludes.

\footnotetext{
${ }^{2}$ Source: Credit Suisse estimates.
} 


\section{Institutional features of pension plans}

\subsection{Description of pension plans}

In the US, employers can choose between two types of retirement plans: a defined contribution plan (DCP) and a defined benefit plan (DBP). DBPs provide specific benefits to employees at retirement whereas DCPs specify only the amount of contributions to be made by the employer to the employee's retirement account. In a DCP, beyond the contribution, the employer has no obligation on any deficit between funds available in the employee's account and the employee's expectations. In a DBP, the employer promises to pay a certain level of benefits and therefore, bears all the investment risk. Under the Employment Retirement Income Security Act (ERISA 1974), firms with defined benefit plans have a legal responsibility to fund the plan with assets sufficient to meet their pension obligations. Because there is no obligation beyond the initial contribution with defined contribution plans, this paper focuses on defined benefit plans. ${ }^{3}$ Henceforth, any reference to pension plans in this paper refers to defined benefits plans (DBPs).

Tax considerations have been an important reason for the popularity of both DBPs and DCPs because company contributions are tax deductible and employee taxes are deferred. At retirement, employee income tax rates are usually lower than during their employment years. DBPs provide an additional tax benefit when plan assets are invested in bonds: since the full pre-tax return on plan assets is delivered to the corporation after payment of corporate taxes and then distributed to shareholders, interest income from bonds held by the plan is taxed at the lower, individual equity income rate.

DBPs create incentives for workers to remain with the firm since pension benefits are based on the years of service and final wage (Ippolito, 1985). While firms have to comply with certain minimum pension contributions requirements, those with underfunded plans have some flexibility which allows them to make additional tax deductible contributions and build financial slack that can be used later against future required contributions if the firm becomes financially constrained.

In recent years, the advantages of defined benefit pension plans have diminished sharply for many companies and some are freezing or terminating their pension plans. ${ }^{4} \mathrm{~A}$ driving force behind the shift from DBPs to DCPs has been an increase in the costs associated with DBPs. As new entrants in many industries have opted not to offer DBP plans, competitive pressures have led many companies to decrease

\footnotetext{
${ }^{3}$ Cash balance pension plans (CBPs) share elements of both DBPs and DCPs and define the benefit as a stated account balance. Because promised benefits do not depend on the value of plan assets, the risks and rewards from the plan's investments are borne by employers and CBPs entail similar legal obligations for employers as DBPs. For this reason, we do not differentiate CBPs from DBPs in the subsequent analysis.

${ }^{4}$ In a freeze, future accruals are discontinued but the existing obligations remain. Despite freezes, pension plans remain commonplace among US companies. The Pension Benefits Guarantee Corp. (PBGC) estimates that most of the single employer benefit plans that were frozen during 2003 were small plans and only about $2.5 \%$ of participants of DBPs were affected by freezes.
} 
pension benefits offered to new employees. Pension contributions have also increased due to a longer than anticipated life expectancy and lower mortality rates.

\subsection{Pension accounting}

The Financial Accounting Standards Board (FASB) mandates that pension assets and liabilities be recorded as off balance sheet items. Pension assets (PA) are measured by their fair market value while pension liabilities are calculated as the actuarial present value of the promised benefits for financial accounting purposes. This measure of the pension liability, also called the projected benefit obligation (PBO), views the company as a going concern and is calculated based on current service and future expected salaries. An alternative measure of pension liabilities is the accumulated benefit obligation (ABO) which reflects the present value of pension benefits based on current employee salaries.

The FASB also mandates that most of the relevant pension related items be disclosed in the footnotes of annual financial statements. The only pension related items recorded on the balance sheet are: (i) the extent to which pension contributions paid were above or less than the recorded pension expense (i.e. the prepaid or accrued pension cost), (ii) in the event of severe underfunding, an additional minimum liability (AML) occurs which is added to the accrued pension cost and offset by an increase in intangible assets and a charge to the book equity on the balance sheet. It is important to note that the AML is an accounting liability and does not reflect the actual pension contribution that firms are required to make.

In addition to these balance sheet amounts, the income statement is affected by the pension expense (also referred to as the pension cost) and the cash flow statement is affected by pension contributions. The rules governing the pension expense and the pension contribution differ. The pension expense is an accounting item intended to reflect a smoothed cost of servicing the pension plan whereas the pension contribution is determined by funding rules established by the Internal Revenue Code and ERISA.

In theory, companies should make contributions so that pension assets completely cover pension liabilities and record these contributions as a pension expense at the same time. In practice, such a strategy would create significant volatility in companies' reported earnings as the value of pension assets and liabilities, and hence the required contributions, fluctuate over time. To avoid this variability, accounting rules allow companies to adopt several pension cost smoothing mechanisms. Because of these smoothing techniques, it is not uncommon for companies to report pension income as part of their operating income when, in fact, the funding status of their pension plan has deteriorated. As an example, in 2003, Boeing Company reported pension liabilities of $\$ 39.9$ billion and pension assets of $\$ 33.2$ billion (a 17\% underfunded plan) while reporting a pension income of $\$ 67$ million on the income statement (i.e. a negative pension cost). 
Thus, focusing exclusively on the balance sheet and income statement creates a distorted image of the economic status of a pension plan. To illustrate this, Figure 1 shows the aggregate underfunding levels relative to the net amounts recognized on the balance sheet prepaid pension assets, accrued pension cost, and AML related items if applicable). In 2000, balance sheets of pension sponsors in Compustat showed net pension assets of $\$ 54$ billion and the plans were in aggregate, overfunded by $\$ 202$ billion. As equity valuations collapsed and interest rates declined in 2002, plans became significantly underfunded by $\$ 620$ billion while net pension assets on the balance sheet dropped to $\$ 3$ billion, giving the impression that plans were sufficiently funded. By 2004, net pension assets increased to $\$ 56$ billion as a result of required minimum contributions that were triggered for many companies. Yet, the plans remained significantly underfunded by about $\$ 575$ billion in 2004. Thus, despite record levels of underfunding during the 20022004 period, companies continued to show a net pension asset on their balance sheets in later years, due ironically to the required contributions triggered by the massive underfunding.

Due to concerns over how the accounting treatment obscures the reality of pension plans, in 2006 FASB adopted new rules (SFAS 158) requiring companies to report the funded status of the pension plans on the balance sheet. By recognizing the current economic value of the pension plans on the balance sheet, the rules eliminate the pension smoothing mechanisms. The income and cash flow statements are unaffected by the new requirements.

\subsection{Funding requirements for pension plans}

The pension expense, the amount recorded on the income statement, is not a tax-deductible item for companies. Instead, the actual pension contribution is tax deductible, provided that sponsoring companies meet certain funding requirements. Companies are required to make a minimum pension contribution each year but have discretion to make additional tax deductible contributions up to a certain level mandated by law. The contributions can be made either in cash, in stock, or in debt. ${ }^{5}$

The minimum required pension contribution depends on the funding status of the plan and equals the normal cost of the plan plus the level of underfunding amortized over 30 years. For the purpose of the minimum contribution, plan underfunding is defined as the difference between the present value of future benefits (PBO) minus plan assets (PA), using the expected return on assets as the discount rate. If the plan is severely underfunded, additional mandatory contributions are required. If pension assets are less than $90 \%$ of $\mathrm{ABO}$, the plan may be liable for an additional contribution and the company must cover the underfunded amount over 3-5 years. Rauh (2006a) provides further discussion of these funding rules.

\footnotetext{
${ }^{5}$ A company can use its own stock to meet these contributions up to a $10 \%$ limit of the total plan assets. See Rauh (2006b) for an analysis of the antitakeover effects of this funding strategy.
} 
Within certain limits known as the full funding limitations (FFL), ${ }^{6}$ companies can make contributions that are larger than the minimum required amounts which can be used to cover mandatory contributions in later years. Tax rules, however, set a limit to the amount of contribution that is tax deductible each year and contributions larger than this amount face an incremental excise tax. This creates the possibility that a firm may make contributions larger than the minimum required amount if the total contribution falls below the plan's annual tax deductible amount. Companies may have incentives to make additional tax deductible contributions when their marginal tax rate is high in order to maximize the tax benefits from pension contributions. In this regard, pension contributions differ from debt obligations where prepayment of debt does not normally provide an incremental tax shield. However, the tax benefits of additional contributions are limited by the tax rules and FFL constraints and GAO-05-294 notes that the maximum tax deductible limit often serves as a real constraint. Thus, the actual importance of this timing strategy and its impact on marginal tax rates is an empirical issue.

When a company fails to meet minimum funding requirements, the PBGC is empowered to recover the pension deficit by filing a claim against the company's assets. In this case, the PBGC claim has the most senior status in bankruptcy proceedings. However, if a company files for bankruptcy without a prior PBGC claim, the priority of the PBGC claim over pension contributions is less clear. The PBGC has maintained that its claims have most senior status, but courts have sometimes deviated from this view. Some precedent legal rulings have upheld the most senior status of the PBGC claim related to the unfunded past service liabilities, but not for the current shortfall incurred during bankruptcy proceedings (and the prior 180 days). When courts have granted priority status for the current shortfall, they have often reduced that portion of the claim in proportion to the workforce reduction during the bankruptcy process. When any portion of the claim is not granted the most senior status, that portion is typically is treated with lower priority, at par with unsecured creditors. Thus, in some bankruptcy situations, the seniority of all or a portion of the pension funding requirement may not hold. ${ }^{7}$

\footnotetext{
${ }^{6}$ The FFL determines the maximum minimum contribution under a complex set of rules. From 1995-2002, FFL was the higher of (a) $90 \%$ of the current liability or the lower of (a) accrued plan liability or (b) $150-170 \%$ of the current plan liability. The maximum tax deductible contribution is based on a similar set of criteria.

${ }^{7}$ The PBGC may initiate the termination of a pension plan if it determines that the plan has not met minimum funding requirements under $\S 412$ of the Internal Revenue Code, if the plan is unable to pay benefits when due, or if the expected loss to PBGC is larger if the plan is not terminated. If the PBGC files a lien prior to the company's filing for bankruptcy, then PBGC's claim is senior and must be satisfied in full before any distribution is made to unsecured creditors. If, however, the company has already filed for bankruptcy, PBGC asserts that the portion of its claim equal to the lien is an administrative expense as a tax incurred by the estate under 11 U.S.C. $\S \S 503(b)(1)(B)$, 507(a)(1) and 29 U.S.C. $\$ 1368(a),(c)(2)$ and has tax priority under 11 U.S.C. $\$ 507(a)(8)$. Any amount of PBGC's claim for unfunded benefit liabilities that is not entitled to priority is asserted as a general unsecured claim. In Columbia Packing Co (B.R. 205, EB Cases 1297, District of Massachussets, 1988), the court upheld the senior status of past service liabilities, but courts have not done so in some other cases.
} 


\subsection{Disclosure}

SFAS 87, issued in 1985, mandated that both the fair value of pension assets (PA) and the projected benefit obligation (PBO) be disclosed in the footnotes of annual financial statements. The accumulated benefit obligation (ABO) is disclosed only until 1998 when SFAS 132 required it to be disclosed only for severely underfunded plans along with the additional minimum liability (AML). Other relevant items disclosed in the pension footnote are the prepaid and accrued pension costs and also the pension expense (or pension cost). Total contributions made by employers became available from 1998 onwards.

Sponsoring companies are also required to file individual pension plan information with the Department of Labor and with the Internal Revenue Service through Form 5500. Both ABO and pension contributions are reported on these forms at the plan level and available to the public with a 2-3 year lag. The major difficulty is that individual pension plans and the parent company are only linked through the EIN (employer identification number), resulting in a large number of plans that cannot be matched to the parent company.

\section{The role of pension plans in corporate capital structure}

Since pension plans are recorded as off-balance sheet items, it is not obvious how their assets and liabilities should be considered from a capital structure perspective. A common practice is to adopt a "netting" approach, where the underfunding of the pension plan is considered to be a liability that is added to balance sheet liabilities. This approach is usually the starting point for analyses conducted by banks and credit rating agencies who typically adjust a firm's leverage, interest, and cash flow coverage ratios to reflect the amount of underfunding or required pension contributions. The advantage of this approach is that it provides a simple comparison across firms with and without pension plans and reflects the immediate claim of the pension plan on the firm's cash flows and assets. The netting approach is common practice with banks for their loan performance monitoring process because it provides a convenient way to examine the impact on metrics on which bank loan covenants are based. The typical implementation of the netting approach only considers the level of underfunding, ignoring plans that are overfunded under the premise that excess pension assets may not be immediately available to satisfy unsecured liabilities in bankruptcy.

While the netting approach is a useful starting point, it has some important limitations if one seeks to understand how pension plans impact overall capital structure decisions. In particular, the underfunding in a given year reflects the plan's claim on cash flows for that year, but ignores the impact the plan may have in future years. All else equal, a large pension plan will face a higher level of underfunding than a small plan for an equivalent percentage decline in asset values and therefore creates more bankruptcy risk for the sponsoring company. This feature is not captured under the netting approach. Thus, considering 
only the underfunding of the pension plan masks the impact of the plan on corporate capital structure decisions.

The limitation of the netting approach is recognized by market participants, including credit rating agencies. FitchRatings (2007) provides a detailed discussion of this issue, comparing two plans, A and B, that are $50 \%$ and $80 \%$ funded, respectively. It notes that "on the surface, one might think that Company B is in a much better position relative to Company A given the differential in funded status. However, because of the absolute size of its PBO underfunded status, its near term cash obligations needed to bridge its $100 \%$ funding target over the next seven years are far greater than Company A's". Similarly, S\&P (2004) notes that "Companies with the same funding ratios in their benefit plans do not, however, necessarily bear the same risks related to their plans. The size of the gross liability is also important because, where the gross liability is large relative to the company's assets, any given percentage change in the liability or related plan assets will have a much more significant effect than if the gross liability had been less substantial."

To circumvent this issue with the netting approach, we adopt a "consolidated" approach to pension assets and liabilities and combine them with the on-balance sheet assets and liabilities in our empirical tests. Several arguments support the consolidation of pension liabilities with debt obligations. First, firms are liable for their pension benefits, just like other corporate liabilities. Pension liabilities can be senior or at par with unsecured financial liabilities, but in no case are they junior to financial debt. Like interest payments, failure to meet minimum pension contributions can trigger bankruptcy. And pension contributions are tax-deductible at the corporate level, similar to interest payments on debt.

Second, pension assets, though legally segregated, are akin to other corporate assets. Appreciations and depreciations in the value of pension assets accrue to shareholders in the form of smaller or larger contributions. Firms may be able to offer additional retirement benefits in exchange for lower increases in employee salaries, and use the resultant financial slack for reinvestment, dividends, share repurchases, or debt reduction. In some situations, companies also can access excess pension assets through plan terminations or conversions to cash balance plans (Petersen, 1992).

Third, just as the choice between debt and equity affects a firm's cost of capital, so does its choice with respect to corporate pensions. This occurs because DBPs differ from other forms of employee compensation because they create an on-going liability for the firm. In this regard, DBP obligations are fundamentally different from DCP obligations and even employee salaries because they do not disappear if an employee leaves the firm. Companies facing financial distress may be able to preserve cash flow by terminating employees thereby saving on compensation expense and DCP payments, but obligations to pay accumulated DBP benefits remain. Jin, Merton and Bodie (2006) present clear evidence that both pension assets and liabilities affect a firm's cost of capital. They show that ignoring pension assets and 
liabilities introduces substantial errors into cost of capital estimation and significantly overstates the true cost of equity. For four large firms, they find an estimation error ranging from $32-139 \%$ for operating asset betas when pension assets and liabilities are ignored.

The consolidation approach has also been adopted by equity research analysts evaluating corporate balance sheets. For example, Credit Suisse (2007) advocates that the first step in adjusting financial ratios is to put the pension assets and the pension liabilities back on the balance sheet. Other studies suggest that the amount of pension assets and liabilities, not just the level of over- or underfunding in a given year, are relevant to investors. Carroll and Neihaus (1998) show that pension assets and liabilities affect firms' market values in a manner similar to regular assets and liabilities. Barth (1991) shows that investors view the fair market value of assets and PBO to exhibit less measurement error than the amounts recorded on the balance sheet. Coronado and Sharpe (2003), and Franzoni and Marin (2006) show that the current level of plan underfunding is insufficient information for investors to understand the impact of pension plans for future earnings and cash flows.

However, there are also important differences between pension assets and liabilities and balance sheet assets and liabilities. If a plan is underfunded, a firm cannot access the pension assets to meet claims arising from general corporate liabilities. Additionally, pension liabilities may encourage risk-taking behavior because they are guaranteed by the PBGC and thus companies may not bear the full costs of imposing high risk on pension beneficiaries. Rauh (2009) however, shows that investment strategies of pension plans do not behave in this manner, but rather are chosen to minimize expected financial distress costs. A further complication arises from the degree to which the plan's asset allocation strategy seeks to immunize asset values to changing values of liabilities. If the plan's investment policy is chosen to achieve full immunization, then changing market conditions would not alter the relative size of its pension assets and liabilities and our consolidation approach would overstate the financial risk of the company. However, the historically large fluctuations in funding levels suggest that most plans are not fully immunized with respect to overall market conditions. Rauh (2008) shows that the investment strategies of pension plans manage to partially offset the value of pension liabilities of current employees, but that ultimately much of the variation in plan allocation strategies is difficult to explain. Thus, variations in asset allocation strategy potentially introduces noise in our consolidated leverage measure, just like variation in the mismatch of risk of balance sheet assets and liabilities introduces in most capital structure tests.

The reporting discretion under pension accounting rules and the off-balance sheet treatment of pensions also make pension liabilities an imperfect substitute for debt. Bergstresser, Desai, and Rauh (2006) show that managers tend to be more aggressive when changes to pension assumptions have a greater impact on reported earnings. The potential to manage earnings through pension plan assumptions 
gives firms a lever to avert some covenant violations on debt, a feature not present with debt obligations alone. Firms appear to care about reporting treatment and often structure financial transactions to keep liabilities off the balance sheet. Shevlin (1987) shows that that firms use off balance sheet R\&D limited partnerships to avoid costs of bond covenant violations. Engel, Erickson, and Maydew (1999) find that firms incur substantial costs in order to manage their balance sheets when they reclassify debt into trust preferred stock. Thus, managers might not treat off-balance sheet pension liabilities as a perfect substitute for on-balance sheet debt liabilities.

Another distinction between interest payments and pension contributions arises from the flexibility of timing of pension contributions as noted earlier. ${ }^{8}$ Within prescribed limits, firms have the ability to make additional tax-deductible contributions in high marginal tax states of the world to maximize the tax benefits. This strategy may lower the marginal rate on debt financing in which case the tax incentives to issue debt would be diminished. In this scenario, firms with pension plans may choose to have lower financial leverage, making them appear conservative in their capital structure on an unconsolidated basis. Consolidating pension and financial debt alleviates but does not fully solve this issue because a pension sponsor would continue to appear more conservative on a consolidated basis than a non-sponsoring firm with only financial debt. We explore whether this tax timing option is likely to create bias in our tests.

Irrespective of whether firms make additional contributions to maximize the value of the timing option, the tax shield provided by pension contributions has the potential to explain why firms appear to adopt conservative leverage ratios from a tax perspective. The tax shield benefits of debt are generally considered to be large relative to the costs of debt financing, and this conservatism of debt policy is often thought to be puzzling. For example, Graham (2000) estimates that the typical firm could double its tax benefits by leveraging up to the point where the marginal tax benefit begins to decline. However, Graham (2000) does not consider the tax shields provided by pensions, which ought to increase the aggregate tax shield realized by firms, all else equal. At the same time, pension contributions may be timed to lower the marginal tax rate for debt financing, thereby lowering the tax benefits from debt. Thus, incorporating pensions into the capital structure has the potential to inform our view as to whether firms adopt overly conservative leverage ratios.

\footnotetext{
${ }^{8}$ In some respects, pension contributions are not directly comparable to interest payments since the latter represent a financing charge on corporate debt while contributions include both a financing charge as well as a funding for a shortfall of pension assets. However, both interest expense and contributions share the feature of tax deductibility and can trigger default in the event of nonpayment.
} 


\section{Data and leverage ratios}

\subsection{Data}

We collect data on all firms covered by Compustat over the 1991 to 2003 period. While Compustat allows us to study a large sample, there are two areas where Compustat's pension data is deficient. The first relates to the netting of certain pension items on the balance sheet, which we describe below and is expected to have a minor, if any, effect on our results. Second, Compustat does not differentiate between domestic and foreign pension plans, just like it does not make this distinction for where the financial debt of a firm is raised. However, the actual tax liabilities of firms with foreign pension plans will be a function of the tax code of the foreign country, a distinction we do not capture in our tests. Two alternative sources of data that provide a finer description of pension plans are 10-K reports and Form 5500. These sources, however, significantly constrain the sample size we can use and also limit the accuracy with which we can identify pension assets and liabilities for some companies. The other advantage of using Compustat is that our adjustments can be easily implemented by future studies on capital structure using Compustat data. In section 7, we provide a discussion of these alternative data sources and the possible effect on our results.

We begin the sample in 1991 because that is the first year when pension cost data is available on Compustat. We exclude utilities, financials, and firms with insufficient information to calculate leverage. This yields 17,015 firm-year observations for plan sponsors and 60,127 firm-year observations for firms without pension plans. Untabulated results show that defined benefit plans are predominantly sponsored by large industrial companies such as automotive, construction, and materials manufacturers and are less prevalent in newer industries such as internet software and telecom services. While there has been a tendency towards plan terminations relative to the number of adoptions, the number of pension sponsoring companies is still very large. In our sample, the number of sponsoring firms peaks at 1,418 in 1996 and declines to 1,095 firms in 2003. As of 2003, almost two-thirds of the S\&P 500 firms sponsor corporate pension plans.

The pension plans are large in relation to the sponsoring companies as shown in Table 1. The aggregate ratio of plan assets to balance sheet assets cleansed of pension items averages $16.4 \%$ (with a median of $9.6 \%$ ) over the sample period. The pension liability averages $31 \%$ (median of $19.2 \%$ ) of the book value of debt. Calculated as a percentage of adjusted operating income (EBIT plus pension cost), pension contributions average $3.9 \%$, while total interest payments on debt average $11.8 \%$. The median ratio of contributions to adjusted EBIT is much smaller at $1.4 \%$. The skewness in pension contributions arises because a few firms have very large pension plans and because contribution amounts tend to be higher in years following equity market declines due to mandatory funding requirements. 


\subsection{Reported versus consolidated leverage}

We create consolidated balance sheets by integrating off balance sheet pension assets and liabilities with reported assets and liabilities. To do this, we first strip the reported balance sheet of items that include components of the pension plan. As described earlier, the vast majority of pension assets and liabilities are not on the balance sheet, but accounting rules require some items that reflect a small part of the pension plan to be included on the balance sheet. Therefore, we make the following adjustments to the balance sheet: (i) we subtract the prepaid pension cost or the accrued pension cost from total assets. ${ }^{9}$ (ii) we cleanse the balance sheet of the additional minimum liability (AML) charge for those firms with severely underfunded plans. As noted earlier, the AML is a liability mandated by FASB for severely underfunded plans reflecting the funding shortfall above the accrued pension cost (net of the prepaid amount) and is offset by an increase in intangible assets on the balance sheet. However, if the unrecognized prior service cost is below the AML, the difference is charged directly to equity. ${ }^{10}$ Thus, cleansing the balance sheet of the AML requires adjusting the book value of equity and deferred taxes. For comparison, we also display leverage ratios using the "netting approach" where the difference between projected benefit obligations (PBO) and pension assets is added to long-term debt using the cleansed balance sheet.

In panel B of table 1, we provide an example of these adjustments using General Motors' 2001 balance sheet. GM sponsors a large pension plan, with pension assets that equal $23 \%$ of the company assets and pension liabilities that are about $28 \%$ of reported liabilities. The plan is severely underfunded and consequently, an AML adjustment is recorded on the balance sheet. While the balance sheet pension accounts show a pension deficit of only $\$ 3.3$ billion (the net amount between prepaid and accrued pension cost), the pension plan is in fact underfunded by $\$ 12.6$ billion. ${ }^{11}$ Book leverage, measured as the ratio of long term debt and its current portion to assets, rises from $39 \%$ (unconsolidated) to $55 \%$ (consolidated) and a much more leveraged company emerges from the consolidated balance sheet. Due to the severe

\footnotetext{
${ }^{9}$ If prepaid pension cost and accrued pension cost are available, both items are used to adjust the balance sheet. After 1998, companies are not required to separately present data on over and underfunded plans and Compustat reports only the netted amount.

${ }^{10}$ The additional minimum liability (AML) is in practice combined with the accrued pension cost (net of the prepaid amount). Between 1998-2003, Compustat mislabels the net amount recognized on the balance sheet as the net prepaid (accrued) pension cost. In the calculation of this item, AML is offset by the intangible assets and the charge to book equity. To properly adjust the balance sheet, we separately subtract AML from current liabilities for this period. In addition, when the AML occurs, the charge to book equity is reported in the footnotes on a pretax basis. In practice, the charge to equity is taken on an after tax basis with the difference charged to deferred taxes.

${ }^{11}$ The amounts described here are from GM's 2001 annual report. Compustat provides only the net value of the recognized asset or liability and the AML. In the empirical analysis that follows, we are constrained to using Compustat, and hence use the net amount of the recognized asset or liability in constructing the consolidated balance sheet. This has a very minor effect on the consolidated leverage ratio because the amounts are quite small relative to the size of pension liabilities. However, it is possible that this simplification creates a slight downward bias in our consolidated leverage ratio because we are ignoring a small asset and a small liability that are being netted out. However, there is no reason to expect that this netting of prepaid cost and accrued benefits creates systematic bias.
} 
underfunding, even the netting approach illustrates that GM is more highly levered than its balance sheet ratios indicate, with a (netted) book leverage ratio of $46 \%$.

We calculate leverage ratios on reported (balance sheet), consolidated (balance sheet and pension), and netted (balance sheet and net funding) amounts. We use two alternative definitions of leverage. We calculate Book D/A as the ratio of long term debt plus the current portion of long-term debt to the book value of assets. Book $D / D+E$ is the ratio of long-term debt to book value of equity plus the book value of long term debt. Market $D / A$ is the ratio of long term debt to the market value of assets. The market value of assets is defined as the book value of assets, minus book value of equity plus the market value of equity. Market $D / D+E$ is the ratio of long-term debt to the market value of equity and long-term debt. For consolidated leverage, we treat the pension liability (PBO) as a long term liability and book equity is redefined as consolidated assets minus consolidated liabilities. For netted leverage we treat the difference between PBO and PA as a long term liability.

Reported and consolidated leverage ratios are shown in Table 2. For pension sponsors, Book D/A rises from a mean of 0.25 (median of 0.23 ) to 0.34 (median of 0.33 ) once pension assets and liabilities are consolidated. Market D/A displays a similar increase from a mean of 0.20 (median of 0.17 ) to 0.27 (median of 0.25). Thus, leverage appears to rise by about one-third when pensions are consolidated. A comparable effect holds if we consider Book $D / D+E$ and Market $D / D+E$ as measures of leverage. In each case, the difference between the consolidated and reported leverage ratio is significant at the $1 \%$ level. Firms do not appear to be more levered if the netting approach is used instead of consolidation. Under the netting approach, all four leverage measures are relatively unchanged. This pattern is similar that found by Rauh (2008) who also observes small differences in leverage ratios under the netting approach using a slightly different methodology.

\section{Marginal tax rates and the tax benefits of pensions}

\subsection{Effect of pensions on marginal corporate tax rates}

Pension contributions are tax deductible and provide the sponsoring company with a potential lever to lower taxable income. The tax benefits of contributions are most valuable when the expected marginal tax rate is high. Thus, firms might make higher pension contributions in high tax states of the world, which in turn, may lower the tax incentives from debt financing. Therefore, a pension plan has the potential to affect the debt issuance decision because it can lower the company's marginal tax rate (MTR). Extent calculations of MTR ignore this discretion in the timing of pension contributions and thus may overstate companies' actual marginal tax rates.

We simulate marginal tax rates following Shevlin (1990) and Graham (1996a, 1996b, 2000, 2003) but modified for the tax treatment of pensions. Since sponsoring companies obtain tax deductions from both 
interest expenses and pension contributions, we sum these amounts to calculate the consolidated interest expense.

We calculate the marginal tax rate by simulating taxable income. Taxable income differs from accounting income due to several factors such as deferred taxes, stock options and tax credits (Hanlon, 2003). The accounting treatment of pensions introduces an additional divergence between accounting and taxable income. Earnings before interest and taxes reflect the pension cost (or income) that is recorded on the income statement, but this expense differs from the pension contribution which is the tax-deductible amount. In general, EBIT as reported in the income statement overstates (understates) taxable income when the pension expense is below (above) the pension contribution. Therefore, we start the simulation by first adding back the pension cost (or income component) to EBIT.

Using the simulated taxable income cleansed of pension items, we simulate MTRs following Graham (1996). Marginal tax rates are defined as the present value of the tax obligation from earning an extra dollar today. We account for the fact that taxes are not paid in all states of nature given the provisions for carrying losses backward or forward and incorporate the probability that taxes will be paid in the future into the simulation. To account for the tax deduction associated with pension contributions, we deduct from operating income the consolidated interest expense, calculated as the sum of interest and pension contributions.

Pension contributions are inferred from the balance sheet items recorded on Compustat. Using the accounting identity that relates contributions to pension expense and net prepaid cost, we calculate contributions as the pension expense (income) plus the change in net prepaid (accrued) pension cost (see Revsine et al, 2005). ${ }^{12} 13$

We calculate consolidated interest expense, including the contribution, as a function of simulated taxable income. We follow Graham (2000) and assume that the interest coverage ratio is constant in profitable states of nature while the dollar interest expense is constant in unprofitable states but

\footnotetext{
${ }^{12}$ An exception to inferring contributions in this manner arises if plans are acquired or split due to acquisitions or divestitures, in which case the calculated contribution may vary from the actual contribution due to certain accounting adjustments that are not fully disclosed, or if some plans are terminated during a year. As we describe below in section 7, based on hand collected data for S\&P 100 firms, we find the extent of these discrepancies to be very minor.

${ }^{13}$ We compare our calculated contributions to those in 10-K filings for the 1998-2003 period and find a close correspondence. For all firms with pension plans during this period, mean and median calculated and reported contributions are virtually identical. Slight differences exist at the tail of the distribution. For example, at the $95^{\text {th }}$ percentile, the calculated contribution is $\$ 150$ million whereas $10-\mathrm{K}$ data shows it to be $\$ 142$ million. Corresponding figures for the $99^{\text {th }}$ percentile are $\$ 669$ million and $\$ 772$ million. One reason for the difference is that the $10-\mathrm{K}$ amounts are reported according to the fiscal year of the individual pension plans which sometimes differ from the fiscal year of the sponsoring company. We use the calculated contributions instead of the $10-\mathrm{K}$ amounts in order to be consistent with the data on interest expense which is also reported over the firm's fiscal year and because using 10-K amounts significantly curtails the available sample size. We obtain qualitatively similar results with both approaches for the subperiod where $10-\mathrm{K}$ contribution amounts are available.
} 
implement this assumption using consolidated interest expense. This approach assumes that in unprofitable states, pension contributions remain at profitable state levels. This assumption creates the possibility that we overstate contributions in unprofitable states if firms were previously making additional contributions in profitable states but revert to the minimum required contributions in unprofitable states. We explore whether this potential timing of voluntary contributions in profitable states affects the MTR calculation. To do so, we need to know the mandatory pension contribution amounts in each year which is unavailable in Compustat. Therefore, we conduct a robustness check using a subsample of firms where we can compute mandatory contributions from Form 5500 for 1992-1998, following the procedure in Rauh (2006a). Using this data, we modify the MTR simulation assuming that only mandatory contributions are made in unprofitable states. For this subsample, we obtain identical MTR estimates if we assume firms only make mandatory payments when unprofitable, suggesting that our assumption does not create bias in our MTR estimates.

Appendix 1 describes the simulation of MTRs in detail. We develop three measures of the marginal tax rate: $\mathrm{MTR}_{\mathrm{NONE}}$ is calculated before any interest or pension deductions, $\mathrm{MTR}_{\mathrm{INT}}$ is calculated after interest payments, and $\mathrm{MTR}_{\mathrm{ALL}}$ is calculated after consolidated interest expense. By comparing $\mathrm{MTR}_{\mathrm{INT}}$ to $\mathrm{MTR}_{\mathrm{ALL}}$, one can observe the effect of pension contributions on marginal tax rates.

Table 2 reports the estimates for marginal tax rates in our sample. Firms with pension plans have higher average pre-financing marginal tax rates (32.6\%) than those without a pension plan (24.7\%), indicating that pension sponsoring firms stand more to gain by incurring additional debt or pension liabilities. Considering only the impact of debt financing on MTR, we find that MTR $_{\text {INT }}$ drops by 2.5 percentage points (32.6\%-30.1\%) for firms with pension plans and by 2.9 percentage points $(24.7 \%$ $21.8 \%$ ) for firms without pension plans. Incorporating pensions, we find that firms with a plan experience a further drop of $0.5 \%$ in MTR. Thus, the cumulative impact of pensions and debt financing on MTR is of comparable magnitude for firms with and without pension plans.

However, MTR after both pensions and debt financing $\left(\mathrm{MTR}_{\mathrm{ALL}}\right)$ remains much higher for firms with a pension plan, despite the fact that these firms have higher financial leverage. This reflects the fact that firms with pension plans are large, mature, and profitable companies with substantial debt capacity as shown in Table 2. Despite the fact that these companies make pension contributions, the contributions are not large enough to have a material impact on the MTR. This suggests that these firms operate with very conservative capital structures, so that even when pension contributions are included, the contributions are not sufficient to move them onto the declining part of the marginal tax curve. Thus, debt conservatism cannot be attributed entirely to the tax effects of pension plans.

We use the simulated marginal tax rates to explore debt conservatism by calculating tax benefit functions. Graham (2000) quantifies the tax advantage of debt for each firm by defining the tax benefit 
function as a series of marginal tax rates, each corresponding to a specific level of interest deductions. If firms balance the tax benefits of debt against the cost of financial distress, firms should operate on the downward sloping part of their tax benefit functions. Like Graham (2000), we define the point where the MTR function starts declining as the "kink". The kink is calculated as the ratio of the amount of interest required to make the tax function slope downward relative to the firm's actual interest expense. When the kink equals one, the firm is exactly at the point where its marginal tax rate starts declining. A kink greater than one implies that the firm operates on the flat segment of the tax benefit curve and can obtain a tax shield equal to the statutory tax rate for an additional dollar of interest expense. Thus, how far the kink is from one is a measure of how conservative a firm is about its debt policy with respect to taxes. In the discussion below, we measure the degree of debt conservatism as the kink minus 1. Graham (2000) documents an average kink of 2.35 for Compustat firms between 1980 and 1994. This indicates that a typical firm could incur substantially more leverage before the tax benefit function starts declining, suggesting a high degree of debt conservatism.

Debt policy appears less conservative once pension liabilities are accounted for. When only interest expenses are considered, the average kink for pension sponsors is 2.03. In other words, pension sponsors could increase interest expense by $103 \%$ and still enjoy the full tax shield from debt in all states of the world. This indicates that firms with pension plans, despite their higher leverage ratios, are substantially underlevered because a doubling of the interest expense is required before their marginal tax rate starts declining. However, once pension contributions are considered, average kink declines to 1.72, implying that incurring $72 \%$ more interest payments would put the firm on the declining segment of the marginal tax curve. Thus, debt conservatism drops from 1.03 to 0.72 , or by $30 \%((1.72-1)-(2.03-1) /(2.03-1)=-$ 0.30). Since pension contributions have a minor effect on MTR, the bulk of the reduced conservatism comes from the pension contribution amounts which reduce the potential tax benefits from additional debt, thereby resulting in a leverage choice that appears less conservative than if pensions are ignored.

To understand whether the $30 \%$ reduction in debt conservatism from pension contributions is meaningful, we compare it to the evidence on the importance of stock option plans. Graham, Lang and Shackelford (2004) study S\&P 100 and NASDAQ 100 firms and find that for these firms, incorporating the tax deductions associated with stock option expenses lowers the kink from 5 to 4 . This implies that debt conservatism drops from 4 to 3 , a reduction of $25 \%((4-1)-(5-1)) /(5-1)=-0.25)$. For a more direct comparison, we also calculate the kink for the 54 plan sponsors included in the S\&P 100 in 2003 and find that for these firms, including pension contributions lowers the kink from 3.47 to 2.71, corresponding to a reduction in debt conservatism from 2.47 to 1.71 , or about $31 \%$. Thus, pension contributions are at least as important as stock options in explaining debt conservatism. While the Graham et al (2004) explanation 
for debt conservatism is most applicable to younger, growth firms, our explanation is more relevant for large and mature companies that are the typical sponsors of pension plans.

It is striking that firms without pension plans display very little evidence of debt conservatism, as the average kink for these firms is close to 1 . This suggests that much of the debt conservatism documented in the literature comes from firms with pension plans, even though we find that these firms actually have higher leverage than non-sponsors, as shown in Table 2. This occurs because plan sponsors have vastly different financial characteristics that endow these firms with much larger debt capacity. Graham (2000) shows that debt capacity, measured by kink, is positively related to firm size, profitability, Z score, and growth opportunities. Pension sponsoring firms share many of these firm attributes - they are larger, have higher operating cash flows, lower volatility of cash flows, higher $\mathrm{Z}$ scores, and higher credit ratings. In untabulated tests, we confirm that in our sample all of these attributes are associated with a higher kink indicating that leverage alone is an insufficient statistic to judge debt conservatism.

Our finding that firms with pension plans are where much of the answer to debt conservatism lies might seem surprising in light of recent high profile bankruptcies of pension sponsoring firms such as Delta Airlines, Northwest Airlines, and Bethlehem Steel. However, inspection of bankruptcy frequencies does not suggest that plan sponsors declare bankruptcy more often than non-sponsors. Using data from the UCLA Bankruptcy Research Database which contains data on all filings under the US Bankruptcy Code for firms with assets exceeding $\$ 100$ million we find that over the 1991-2003 period, 1.2\% of all pension sponsors in the Compustat universe filed for bankruptcy during this period, compared to $1.5 \%$ of non-sponsoring firms that declared bankruptcy. The lower incidence of bankruptcy filings for pension sponsors is consistent with the higher credit ratings for these firms shown in Table 2. Thus, the few high profile bankruptcies of plan sponsoring firms do not appear to be representative of the bankruptcy risk of the typical plan sponsor.

\subsection{Tax benefits of pension contributions}

The modest effect of pensions on average marginal tax rates implies that the tax benefits of pension contributions ought to be large. To explore this, we now quantify the tax benefits. We calculate the tax benefits of financial debt and consolidated debt by integrating the area below the benefit function up to the point of the consolidated interest expense. The present value of tax benefits from current and future deductions is calculated under the assumption that tax shields are perpetual, using Moody's average bond yield as the discount rate.

Table 3 shows that the average ratio of consolidated interest expense (pension contributions and interest) to interest expense is 1.56 , indicating that pension contributions are a very important source of deductions for some firms with pension plans. The average ratio of the tax benefit including pensions to 
the tax benefit from debt alone is 1.31 , implying that the average tax benefit of pensions is almost onethird of that of financial debt. These effects appear to be driven by firms with very large plans since the medians of both ratios are close to one. To see the impact of pension contributions in terms of the size of the sponsoring firm, we calculate the capitalized tax benefits as a percentage of firm value. On average, tax savings associated with pensions amount to $2.1 \%$ of book assets $(14.9 \%-12.8 \%)$ and $1.5 \%$ of the market value $(11.4 \%-9.9 \%)$ of the firm.

Due to the skewness in the distribution of pension contributions, the average effects documented above mask a larger impact for firms that have a large pension plan. As we describe in section 6 below, both the incidence and the size of the pension plan are systematically related to firm characteristics. Therefore, by ignoring pension liabilities, capital structure tests face the possibility of introducing bias which is likely to be more severe for firms that sponsor large pension plans.

To examine this possibility, Table 4 reports the MTRs, tax benefits, and debt conservatism according to the size of the pension plan, with decile 1 representing the smallest plans and decile 10 representing the largest plans. The first three columns show that the effect of incorporating pensions into the MTR is much greater for firms with large plans. Firms in the largest decile have a drop in MTR of $1.3 \%$ compared to only $0.1 \%$ for firms in the smallest decile. The implication of this pattern is that by ignoring pensions, the standard calculation for the marginal tax benefit of incremental debt is overstated for firms with large pension plans. The following 3 columns show that when the tax deduction for the pension contribution is considered, the total tax benefit from consolidated interest (including pension contributions) is higher than the tax benefit from interest expense. Highlighting the importance of considering both the pension contribution and its effect on MTR, the difference in tax benefits is much larger for firms with bigger pension plans.

The size of the pension plan also affects the degree to which firms are conservative on debt policy. Although the relation between the kink and plan size is not monotonic, firms with large plans operate much closer to a kink of 1 than firms with small plans. Once pensions are considered, debt conservatism drops by $72 \%(0.34 /(1.47-1))$ for firms in the largest decile of plan size, but by only $4.3 \%(0.04 /(1.83-1))$ for the smallest decile.

\section{Relation between the pension liabilities and balance sheet debt}

We now examine the relationship between pension liabilities and financial debt. In the tradeoff theory framework, firms set target capital structures by balancing the costs against the benefits of their debt obligations. Pension liabilities and financial debt both provide tax incentives and impact the probability of financial distress. Companies sponsoring pension plans should therefore have lower financial debt, all else equal. As noted earlier, however, pension liabilities and debt are unlikely to be perfect substitutes 
because of the PBGC insurance, the off-balance treatment of pensions, and the tax timing option with contributions.

\subsection{Econometric model}

We test whether firms with pension liabilities employ less financial debt, but need to address the endogeneity of pension liabilities. We do so by employing three equations. First, we see how firms selfselect into becoming pension plan sponsors. Conditional on being a plan sponsor, we estimate the amount of pension liabilities. The predicted value of pension liabilities is then used in a regression for the use of financial leverage. Thus, we employ the following model:

$$
\begin{array}{cl}
D B P^{*}=a_{0}+a_{1} X_{1}+a_{2} Z_{1}+\varepsilon & \text { (Self selection equation) } \\
D B P=1 \text { if } D B P^{*}>0 \text { and } D B P=0 \text { if } D B P^{*} \leq 0 & \text { (Pension benefits equation) } \\
D B P^{*}>0: P E N S I O N=c_{1}+c_{2} * X_{2}+c_{3} Z_{2}+v & \\
L E V=b_{1}+b_{2} * D B P+b_{3} * D B P * P E N S I O N+b_{3} X_{3}+\eta & \text { (Leverage equation) }
\end{array}
$$

where the latent variable $D B P^{*}$ is the expected net benefit from sponsoring the pension plan, PENSION is the expected pension obligation (normalized by consolidated assets), and LEV is the long term balance sheet debt (normalized by consolidated assets). The error terms $(\varepsilon, v, \eta)$ are assumed to follow a multivariate normal distribution. While the leverage equation is the focus of the analysis, the self selection equation is used to address the selectivity bias concern and the pension benefits equation is intended to control for the endogeneity of pension liabilities in the leverage equation.

The net benefit of sponsoring a pension plan is unobservable and therefore the selection equation cannot be estimated directly. However, firms become sponsors when the net benefit is positive and choose not to become sponsors when the net benefit is negative, a binary choice that is observable. Consequently, we define $D B P$ as equal to one when a pension plan exists and zero otherwise.

The estimation is conducted as follows. In the first stage, we jointly estimate the net benefit of sponsoring a DBP and the size of pension benefits in a self selection model framework, using maximum likelihood estimation. The set of independent variables $X_{1}$ and $Z_{1}$ are separated out based on their inclusion in the pension benefit equation. $Z_{1}$ is a vector of identification variables in the selection equation, whereas $X_{1}$ is a vector of independent variables used in both the selection and the pension benefit size equation. Fitted values of pension benefits are, therefore, derived from a selectivity-bias corrected pension benefit equation. In the second stage, we jointly estimate the net benefits of being a 
pension plan sponsor and the amount of financial debt on the balance sheet in a treatment effects model, using predicted pension benefits instead of actual pension liability. The variable $L E V$ is modeled as a function of the binary choice $D B P$, the predicted level of the pension obligation PENSION, and the observed variables $X_{3}$.

This methodology corresponds to the two-stage least squares (2SLS) technique to correct for endogeneity, with the addition of the self selection adjustment. As in the case of the 2SLS, this procedure generates incorrect estimates of the variance-covariance matrix because the estimate of the error term variance is computed using residuals calculated with estimated rather than actual values of the endogenous variables. To correct for the potential correlation of residuals across firms and across time, we use bootstrapped standard errors.

\subsection{Variables used}

We begin by describing the variables we use in the pension selection and the benefits equations. We expect a number of variables to be associated with both the likelihood that a firm offers a pension plan and the size of the benefits. Our estimation of the pension selection decision includes variables that are associated with the decision to sponsor a plan. For identification purposes, we require an instrument that is uncorrelated with the size of the pension liability $\left(Z_{1}\right)$. To identify the pension liability equation, we also need to include a subset of variables that only affect the size of pension liabilities $\left(Z_{2}\right)$ and not financial debt.

We expect that the decision to offer a pension plan and the size of the pension benefits will be related to the need for employees to invest in firm-specific human capital. Ippolito (1985) finds that defined benefit plans create strong incentives for workers to remain with the firm because they suffer wealth losses if they quit early. Mitchell (1982) and Schiller and Weiss (1980) show that sponsoring firms have lower employee turnover. Thus, industries requiring firm-specific human capital investment in employees are likely to offer pension plans to encourage lower employee turnover. Therefore, we use the median employee tenure (TENURE) for firms in the same 2-digit industry to explain the pension decision and pension size.

Petersen (1994) finds that the financial characteristics of the sponsor influence the type of pension plan offered by the company. Due to minimum contribution requirements, firms with more volatile cash flows are less likely to offer retirement benefits to employees. Therefore, both the level and volatility of the firm's profitability are expected to affect the decision to sponsor a plan and the amount of pension benefits offered to employees. Accordingly, we include the ratio of pre-tax operating income to assets $(R O A)$ and its standard deviation over the past 10 years (ROA VOL) in the pension selection and size equations. Pension plans also entail potential financial distress costs due to the minimum contribution 
requirements, suggesting that firms with higher financial distress costs ought to be less likely to offer pension benefits. Since financial distress is more costly for high growth firms, we use the market to book ratio $(\mathrm{MB})$ as a proxy for growth opportunities in predicting pension plan choice and size.

Controlling for self-selection requires variation in the pension choice decision that is independent of pension size or financial leverage. Since we use a probit model to estimate the pension plan decision, one source of identification comes from the nonlinearity introduced by maximum likelihood estimation that contributes to the isolation of the pension choice variable from pension size and financial leverage (Heckman and Navarro-Lozano, 2004). To provide an additional layer of identification, we add the degree of unionization of the industry (UNION), measured as the percentage of unionized workers in an industry, as an instrument in the pension selection equation $\left(Z_{1}\right.$ variable in the model). An organized labor force is likely to have substantial negotiation power over the adoption of a pension plan and may be able to hinder the termination of the plan. However, the percentage of unionized workers in an industry should be uncorrelated to the size of pension benefits. ${ }^{14}$ We collect data on unionization from annual issues of the Current Population Survey by the Department of Labor which provides the percentage of the workforce in an industry employed by unions. We note that a potential concern with using industry unionization as an instrument for the pension choice decision is the possibility that it is correlated with leverage. Perotti and Spier (1993) and Matsa (2009) argue that capital structure is used as a bargaining tool in unionized firms, raising the prospect of such a correlation. In our sample, however, we find industry-level unionization to be uncorrelated with financial leverage.

To identify the pension benefits equation, we use PLAN AGE as an instrument. Older plans are likely to have accumulated more pension benefits, and therefore we expect that this variable is positively correlated with pension plan size. We measure PLAN AGE by the number of years with pension data on Compustat. We do not have any a priori reason to expect that the age of the plan would be correlated with leverage. To reflect the overall shift away from defined benefits plans to defined contribution plans, we estimate both the pension selection and size equations with year fixed effects.

Estimates from the pension choice model are shown in column (1) of Table 5. As expected, firms are more likely to have a pension plan when they are large and in more unionized industries. Higher profitability, low market to book ratios, high tangible assets, and higher earnings volatility are also positively associated with the incidence of pension plans. Thus, many of the variables commonly thought of as affecting capital structure are linked to the decision to sponsor a pension plan. Column (2) shows that the size of pension liabilities is increasing in the age of the plan and the median tenure of employees

\footnotetext{
${ }^{14}$ It is possible, for example, that a unionized work force makes it easier for a firm to renegotiate pension benefits during times of financial distress. In our data, we find pension benefits and the degree of industry unionization to be uncorrelated.
} 
in the industry. Surprisingly, the size of pension benefits is negatively related to profitability. Therefore, while sponsoring companies are more profitable on average, those with large pension plans are less profitable. This may be because large contributions constrain firms from pursuing their optimal investment policy, as is suggested by Rauh (2006a).

We use these estimates to calculate the predicted value of pension liabilities. The treatment effects model measures the effect of pension obligations on financial leverage. In addition to the pension choice variable, DBP, and the predicted pension liability, PENSION, we include several other control variables. Following Rajan and Zingales (1995), Graham (1996a), and Frank and Goyal (2007), these variables include the marginal tax rate before financing activities $\left(M T R_{\mathrm{NONE}}\right)$, firm size (LOG ASSETS), the market to book ratio $(M B)$, the probability of financial distress (ZSCORE), an indicator for negative book equity (OENEG), operating profit volatility (ROA VOL), the ratio of tangible to total assets (COLLATERAL), and the median industry leverage ratio (IND. MEDIAN LEV).

The results of the treatment effects model are shown in column (1) of Table 6. We find that the coefficient on pension liabilities is -0.36 and significant at the $1 \%$ level. Thus, firms appear to adjust their leverage ratios downwards in the presence of pension liabilities. This finding indicates that observed leverage ratios are affected by the size of firms' pension obligations. The estimated coefficient on pension liabilities is less than 1, implying that managers only partially substitute debt for pension obligations. As noted earlier, this partial substitution could arise for any of the reasons that make financial debt and pension obligations less than perfect substitutes.

Diagnostic tests suggest that the treatment effects model appears to be an appropriate specification, with evidence that controlling for self-selection is important. The Hausman test for exogeneity of pension liabilities with respect to leverage is rejected. PLAN AGE and TENURE also serve as valid instruments in the pension choice equation using the Stock and Yogo $(2002,2005)$ test for weak identification.

One concern with the 2SLS framework is its sensitivity to the choice of instrumental variables as shown by Coles, Lemmon and Meschke (2007). As an alternative to the treatment effects model, column (2) of Table 6 presents results OLS regression results using the actual pension liability instead of its predicted value. This specification also suggests partial substitution between pension liabilities and debt. The coefficient on pension liabilities is -0.39 in this specification, qualitatively similar to the estimate from the treatment model. A difference between the two models, however, is that the OLS specification suggests that firms with pension plans are more levered, whereas this result does not hold in the treatment model because that model controls for the self selectivity of firms offering pension plans.

Recently, Lemmon, Roberts, and Zender (2008) have argued that most traditional tests of capital structure that use pooled OLS regressions are misspecified due to unobserved time invariant factors that are correlated with leverage. Specifically, they show that pooled OLS estimates tend to be of much larger 
magnitude than estimates from firm fixed effects models. To evaluate this concern, column (3) also displays a firm fixed effects model that includes year fixed effects. We find that the coefficient for pension liabilities remains negative and significant, with a point estimate of -0.25 . While the coefficient on pension liabilities drops in the fixed effects framework, the drop is much smaller than the typical 60$80 \%$ reduction in point estimates for most other determinants of leverage observed by Lemmon et. al.

To further understand how pension plans affect leverage, we conduct an analysis of covariance and decompose the variation in leverage attributable to different factors. Lemmon et. al. (2008) show that most of the variation in capital structure arises from time-invariant factors rather than from temporal variation in capital structure determinants. Since pension plans tend to be in place for long periods of time, they are a candidate for such a time-invariant factor. To evaluate this, we deconstruct the variation in leverage due to different factors, closely following the methodology in Lemmon et. al. (2008). Column (3) of Table 7 shows that traditional determinants of capital structure including industry fixed effects

yield an $\mathrm{R}^{2}$ of 0.42 . Adding firm fixed effects in column (4) increases the $\mathrm{R}^{2}$ to 0.74 . When we add pension liabilities to the list of capital structure variables in column (5), the $\mathrm{R}^{2}$ rises to 0.47 . Thus, pension liabilities appear to account for about $16 \%((0.47-0.42) /(0.74-0.42))$ of the firm fixed effect, implying that pensions may be one of the time-invariant factors shown to be important by Lemmon et. al.

\section{Robustness checks}

Our analysis relies on Compustat where the prepaid pension cost, accrued liability, and intangible assets are disclosed as net amounts. This may introduce measurement error (though probably not bias) into the consolidated leverage ratio calculation. Compustat also does not separate out foreign pension plans that are subject to foreign regulations which may differ from ERISA. Calculated contribution amounts may also differ slightly from actual contributions due to acquisition or termination related adjustments. To examine these issues, we hand collect pension data for S\&P 100 index constituents in 2003. These very large firms are more likely to have foreign plans and are more likely to acquire firms. Thus, this sample should provide an upper bound on the measurement issues arising from Compustat.

Eighty-five of the S\&P 100 companies sponsor defined benefit plans, and 25 of them have foreign pension plans. We compare Compustat data for these 85 sponsoring firms with data from two alternative data sources. The first is the $10-\mathrm{K}$ footnote disclosure on defined benefit plans which details the balance sheet recognized amounts and foreign pension plans. This source yields an average consolidated book leverage ratio that is $1 \%$ higher than when using Compustat, but the consolidated market leverage ratio is unchanged.

An alternative data source is Form 5500, which is filed with the Department of Labor by each sponsor for each individual pension plan. However, using this data requires consolidating each plan (and 
identifying each fiscal year that contributions are applied to) to the sponsoring company, a task hindered by the lack of a common identifier between Compustat and Form $5500 .{ }^{15}$ For the subsample of 85 S\&P 100 firms for which hand-collected data from $10-\mathrm{K}$ filings, we are able to match only 58 companies from Form 5500 filings. For this subset of firms, the aggregated contribution amounts are statistically different from those obtained from 10-K filings, either because these forms are unavailable for all plans or because the lack of identifiers causes us to miss some individual plans in the consolidation process. More importantly, we are unable to rely exclusively on Form 5500 data for our analysis because the component of the pension cost or income that would correspond to these plans is not disclosed, and thus an important component for the calculation of MTRs is lacking.

\section{Conclusion}

We study the capital structure implications of defined benefit pension plans using a comprehensive sample of US companies. We show that firms are substantially more levered when their pension assets and liabilities are brought back on the balance sheet highlighting that the reported leverage ratios of companies can vary significantly from their economic indebtedness.

Pension contributions affect marginal corporate tax rates, primarily for firms with large plans. Since these contributions lower the marginal tax rate, estimates of interest tax shields that ignore pensions overestimate the incremental tax benefits from debt financing. At the same time, pension contributions themselves provide sizeable tax benefits. We estimate that the average value of tax shields from pension contributions is about one-third as large as the value of interest tax shields for firms with defined benefit pension plans. On average, the tax benefits from pensions account for about $1.5 \%$ of the value of the firm.

There has been significant attention paid to why firms appear to adopt conservative financial policies and do not lever up to the point when their marginal tax curve starts declining. Incorporating pensions shows that firms appear to follow less conservative financial policies, primarily because pension contributions can be large and provide a source of valuable tax shields. The conservatism of debt policy, as measured by the distance of the kink from one, declines by about $30 \%$ for firms with pension plans. Thus, the existence of pension plans appears to explain a significant part of debt conservatism, though it is clearly not the whole story. In this regard, our findings complement the existing explanations for debt conservatism that have been studied in the literature.

\footnotetext{
${ }^{15}$ Since 1998, Form 5500 is linked to Compustat only through the EIN (employer identification number). The sponsoring entity could be a controlled subsidiary choosing to file taxes separately from the parent (therefore having a different EIN). Subsidiaries that are at least $80 \%$ owned by the parent have the option to file for taxes separately, while remaining consolidated with the parent company for financial purposes. Another complication arises when the company's plan year differs from its fiscal year. Bodie (1990) and Rauh (2006a) provide a detailed comparison of reporting under Form 5500 and the 10-K filings on which Compustat data is based.
} 
Finally, we show that firms consider their pension assets and liabilities in determining their leverage ratios. We show that a 1 percentage point increase in the pension liability to total assets ratio is associated with a 0.36 percentage points decrease in the leverage ratio. Thus, ignoring pension plans in capital structure tests runs the risk of introducing bias, since the existence and size of pension plans is systematically related to firm characteristics. 


\section{Appendix 1}

\section{Estimation of the corporate marginal tax rate}

Marginal tax rates are simulated following the methodology of Shevlin (1990) and Graham (2000). The marginal tax rate (MTR) is defined as the present value of the tax obligation from earning an extra dollar today. The calculation requires the estimation of the taxable income for the current year and also for all future years the tax loss carryforwards are permitted by the tax code.

Taxable income is first estimated from Compustat as earnings before interest and taxes. We adjust earnings for the tax treatment of pensions by adding back the reported pension cost (income). To account for operating leases we include one-third of the rental expense, the estimated proportion of the rental payment that is not due to depreciation following Graham et. al (1998). We also incorporate extraordinary or discontinued items and subtract the deferred tax expense. The latter term is divided by the appropriate statutory tax rate so that it is expressed on a pre-tax basis.

We forecast taxable income based on the assumption that earnings follow a random walk with drift. We update means and variances every year on a rolling historical basis. We calculate the present value of the tax bill based on the progressive nature of the corporate tax schedule, using as a discount rate the average corporate bond yield. Carryback tax losses are not discounted provided that interest is not paid on any tax refunds. Next, we add $\$ 10,000$ to current year income and recalculate the tax liability. The difference between the two tax bills represents the present value of an additional dollar earned, which is the marginal tax rate.

To incorporate the uncertainty of earnings, we repeat the simulation procedure 50 times, based on a new forecast of the taxable income. The expected MTR is calculated as the average MTR over all simulations for each individual firm-year. This is the firm marginal tax rate in the absence of financing (debt or pension), which we denote in the paper by $\mathrm{MTR}_{\mathrm{NONE}}$.

In order to identify the tax benefit function we repeat the simulation for different levels of the interest expense. Following Graham (2000), we assume that the interest coverage ratio beyond the current year is constant at the current year value in profitable states, but we maintain current year dollar interest expense in unprofitable states.

Along the curve, we identify $\mathrm{MTR}_{\mathrm{INT}}$ which is the marginal tax rate corresponding to current level of debt financing (excluding pensions) and also the $\mathrm{MTR}_{\mathrm{ALL}}$ calculated after all financing (debt and pensions). 


\section{References}

Almeida, H. and T. Philipon, 2007, The risk-adjusted cost of financial distress, Journal of Finance 62, 2557-86.

Altman, E. I., 1968, Financial ratios, discriminant analysis and the prediction of corporate bankruptcy, Journal of Finance 23, 589-609.

Barth, M. E., 1991, Relative measurement errors among alternative pension asset and liability measures, The Accounting Review 66 (3), 433-463.

Bergstresser, D., M. A. Desai, and J. Rauh, 2006, Earnings manipulation, pension assumptions and managerial investment decisions, Quarterly Journal of Economics 121, 157-195.

Bodie, Z., 1990, The ABO, the PBO, and pension investment policy, Financial Analysts Journal 46, 2734.

Carroll, T. and N. Niehaus, 1998, Pension plan funding and corporate debt ratings, Journal of Risk and Insurance, 65 (3). 427-43.

Coles, J. L., M.L. Lemmon and F. Meschke, 2007, Structural models and endogeneity in corporate finance: The link between managerial ownership and corporate performance, working paper, University of Utah.

Coronado, J. L. and S. A. Sharpe, 2003, Did pension plan accounting contribute to a stock market bubble?, Brookings Papers on Economic Activity 1, 323-359.

Credit Suisse, 2007, The magic of pension accounting, Americas/United States Equity Research.

Engel, E., M. Erickson, and E. Maydew, 1999, Debt-equity hybrid securities, Journal of Accounting Research 37 (2), 249-274.

Faulkender, M., and M. Petersen, 2006, Does the source of capital affect capital structure?, Review of Financial Studies 19, 45-79.

FitchRatings, 2007, Analysis of U.S. Corporate Pensions, Criteria Report.

Frank, M., 2002, The impact of taxes on corporate defined benefit plan asset allocation, Journal of Accounting Research 40 (4).

M. Z. Frank and V. K. Goyal, 2007, Capital structure decisions: Which factors are reliably important?", Financial Management, forthcoming.

Franzoni, F. and J. Marin, 2006, Pension plan funding and stock market efficiency, Journal of Finance 61, 921-956.

Graham, J., 1996a, Debt and the marginal tax rate, Journal of Financial Economics 41, 41-73.

Graham, J., 1996b, Proxies for the corporate marginal tax rate, Journal of Financial Economics 42, 187221.

Graham, J., 2000, How big are the tax benefits of debt? , Journal of Finance 55, 1901-1941. 
Graham, J., 2003, Taxes and corporate finance: A review, Review of Financial Studies 16, 1074-1128.

Graham, J., and C. Harvey, 2001, The theory and practice of corporate finance: Evidence from the field, Journal of Financial Economics 60, 187-243.

Graham, J., M. Lang, and D. Shackelford, 2004, Employee stock options, corporate taxes and debt policy, Journal of Finance 59 (4), 1585-1618.

Graham, J., M. Lemmon, and J. Schallheim, 1998, Debt, leases, taxes, and the endogeneity of corporate tax status, Journal of Finance 53, 131-161.

Graham, J., and A. Tucker, Tax shelters and corporate debt policy, 2006, Journal of Financial Economics $81,563-594$

Hanlon, M., 2003, What can we infer about a firm's taxable income from its financial statements? National Tax Journal, 831-864.

Heckman, J.J., Navarro-Lozano, S., (2004), Using matching, instrumental variables, and control functions to estimate economic choice models, Review of Economics and statistics 86, 30-57.

Ippolito, R. A., 1985, The economic function of underfunded pension plans, Journal of Law and Economics 28, 611-651.

Jin, L., R. C. Merton and Z. Bodie, 2006, Do a firm's equity returns reflect the risk of its pension plan?, Journal of Financial Economics 81, 1-26.

Lemmon, M. L., M. R. Roberts and J. F. Zender, 2008. Back to the Beginning: Persistence and the CrossSection of Corporate Capital Structure, Journal of Finance, vol. 63(4), 1575-1608.

MacKie-Mason, J., 1990, Do taxes affect corporate financing decisions?, Journal of Finance 45, 14711493.

Matsa, D.A., 2009, Capital structure as a strategic variable: Evidence from collective bargaining, Journal of Finance, forthcoming.

Mitchell, O., 1982, Fringe benefits and labor mobility, Journal of Human Resources 17(2), 286-298.

Molina, C. A., 2005, Are firms underleveraged? An examination of the effect of leverage on default probabilities, Journal of Finance 60(3), 1427-1459.

Perotti, E.C. and K.E. Spier, 1993, Capital structure as a bargaining tool: The role of leverage in contract renegotiation, American Economic Review 83, 1131-1141.

Petersen, M. A., 1992, Pension reversions and worker-stockholder wealth transfers, The Quarterly Journal of Economics 107(3), 1033-1056.

Petersen, M. A., 1994, Cash flow variability and firm's pension choice: A role for operating leverage, Journal of Financial Economics 36, 361-383.

Rajan, R. G. and L. Zingales, 1995, What do we know about capital structure: Some evidence from international data, Journal of Finance 50, 1421-1460. 
Rauh, J., 2006a, Investment and financing constraints: Evidence from the funding of corporate pension plans, Journal of Finance 61, 33-71.

Rauh, J., 2006b, Own company stock in defined contribution pension plans: A takeover defense? Journal of Financial Economics 81, 379-410.

Rauh, J., 2008, The effects of financial condition on capital investment and financing: Evidence from variation in pension fund asset performance, Working paper, University of Chicago.

Rauh, J., 2009, Risk shifting versus risk management: Investment policy in corporate pension plans, Review of Financial Studies 22, 2487 - 2533.

Revsine, L., Collins, D. W., and Johnson, W.B., 2005, Financial Reporting and Analysis, $3^{\text {rd }}$ ed., Pearson Prentice Hall.

Schallheim, J. and K. Wells, 2006, Debt and taxes: A new measure for non-debt tax shields, working paper, University of Utah.

Shevlin, T., 1987, Taxes and off balance sheet financing: research and development limited partnerships, The Accounting Review 52(3), 480-509.

Shevlin, T., 1990, Estimating corporate marginal tax rates with asymmetric tax treatment of gains and losses, The Journal of the American Taxation Association, 12, 51-67.

Schiller, B. and R. Weiss, 1980, Pension and wages: A test for equalizing differences, Review of Economics and Statistics 63, 529-538.

Standard and Poors, 2004, Corporate Ratings Criteria - Post Retirement Obligations.

Stock, J. H., J. H. Wright, and M. Yogo. 2002. A Survey of Weak Instruments and Weak Identification in Generalized Method of Moments, Journal of Business \& Economic Statistics 20(4): 518-29.

Stock, J. H., and M. Yogo. 2005. Testing for Weak Instruments in Linear IV Regression. In Identification and Inference for Econometric Models: Essays in Honor of Thomas Rothenberg, ed. D.W. Andrews and J. H. Stock, 80-108. Cambridge University Press.

Thomas, J. K., 1988, Corporate taxes and defined benefit plans, Journal of Accounting and Economics $10,199-237$.

Wall Street Journal, 2005, How companies make the most of pensions, January 24, page R3. 
Figure 1

Aggregate level of pension funding

This figure shows the aggregate level of pension funding as the difference between aggregate pension assets and liabilities versus net balance sheet recognized amounts. The pension liability as measured by the projected benefit obligation and the fair value of assets are both disclosed in the footnotes of the financial statements. Until 1998, sponsoring companies were required to disclose separately information for underfunded and overfunded plans, and therefore we aggregate the information. The net amount recognized on the balance sheet is the sum between the accrued pension liability, the prepaid pension liability, additional minimum liability, the charge to book equity and the intangible asset.

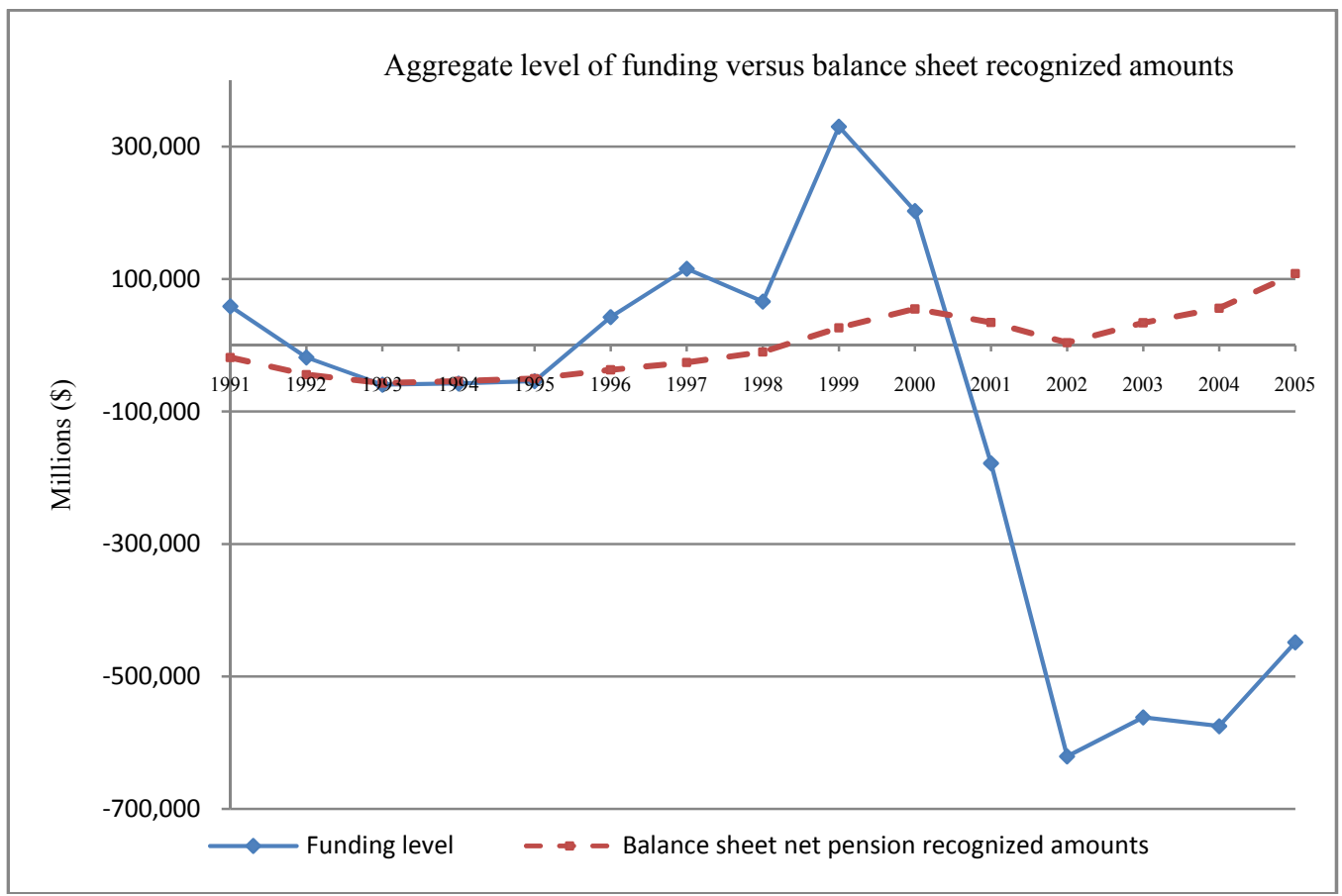


Table 1

\section{Balance sheet pension plan exposure}

\section{Panel A: Firms reporting pension assets and liabilities}

The sample includes all Compustat firms reporting pension assets and liabilities in the footnotes of the annual financial statements, from 1991 to 2003 and where data is available to calculate leverage ratios. The pension liability as measured by the projected benefit obligation, the fair value of assets and the pension cost are disclosed in Compustat. Contributions are estimated as the pension cost plus the change in the net prepaid pension cost (excluding the additional minimum liability) that is recognized on the balance sheet. Total book debt is calculated as book assets minus book equity. Adjusted operating income (EBIT) is the operating income plus the pension cost.

\begin{tabular}{|c|c|c|c|c|c|c|c|c|}
\hline Year & $\begin{array}{l}\text { No. } \\
\text { firms }\end{array}$ & $\begin{array}{l}\text { Ratio of } \\
\text { plan assets } \\
\text { to firm } \\
\text { assets }\end{array}$ & $\begin{array}{l}\text { Ratio of } \\
\text { pension } \\
\text { liability to } \\
\text { total book } \\
\text { debt }\end{array}$ & $\begin{array}{l}\text { Ratio of } \\
\text { Contributions } \\
\text { to EBIT } \\
\text { (adjusted for } \\
\text { pensions) }\end{array}$ & $\begin{array}{l}\text { Ratio of } \\
\text { Interest to } \\
\text { EBIT } \\
\text { (adjusted } \\
\text { for } \\
\text { pensions) } \\
\end{array}$ & $\begin{array}{l}\text { Interest on } \\
\text { debt (\$Mil) }\end{array}$ & $\begin{array}{l}\text { Pension } \\
\text { contributions } \\
\text { (\$Mil) }\end{array}$ & $\begin{array}{l}\text { Pension } \\
\text { cost (\$Mil) }\end{array}$ \\
\hline 1991 & 1264 & 0.158 & 0.316 & 0.034 & 0.321 & 96.540 & 12.910 & 11.972 \\
\hline 1992 & 1300 & 0.160 & 0.318 & 0.061 & 0.258 & 86.889 & 17.010 & 12.495 \\
\hline 1993 & 1342 & 0.162 & 0.319 & 0.030 & 0.171 & 76.764 & 15.013 & 14.269 \\
\hline 1994 & 1374 & 0.143 & 0.280 & 0.051 & 0.169 & 76.767 & 32.457 & 18.950 \\
\hline 1995 & 1400 & 0.199 & 0.317 & 0.034 & 0.159 & 80.661 & 27.184 & 15.333 \\
\hline 1996 & 1418 & 0.206 & 0.314 & 0.040 & 0.275 & 81.972 & 30.939 & 14.398 \\
\hline 1997 & 1408 & 0.166 & 0.298 & 0.038 & 0.106 & 84.181 & 22.304 & 12.916 \\
\hline 1998 & 1367 & 0.167 & 0.301 & 0.029 & 0.113 & 91.816 & 40.317 & 14.691 \\
\hline 1999 & 1287 & 0.178 & 0.288 & 0.024 & 0.254 & 110.126 & 33.180 & 8.008 \\
\hline 2000 & 1253 & 0.160 & 0.268 & 0.038 & 0.027 & 130.699 & 45.061 & 1.675 \\
\hline 2001 & 1250 & 0.140 & 0.287 & -0.009 & -0.698 & 145.426 & 35.299 & 14.017 \\
\hline 2002 & 1257 & 0.124 & 0.296 & 0.054 & 0.128 & 138.653 & 63.319 & 23.468 \\
\hline 2003 & 1095 & 0.161 & 0.374 & 0.091 & 0.205 & 139.641 & 89.516 & 40.631 \\
\hline Mean & & 0.164 & 0.305 & 0.039 & 0.118 & 101.728 & 34.909 & 15.316 \\
\hline Median & & 0.096 & 0.192 & 0.014 & 0.140 & 15.943 & 0.999 & 1.188 \\
\hline $\mathrm{N}$ & & 16,096 & 17,015 & 15,285 & 16,166 & 16,684 & 15,348 & 16,524 \\
\hline
\end{tabular}


This table shows the impact of pension plan assets and liabilities on the balance sheet based on consolidated and netted adjustments. For consolidated leverage, pension assets and liabilities are treated as corporate assets and long term liabilities. For netted leverage, the net pension liability is treated as long term debt. All pension related items are removed from the balance sheet before adjustments are made. The prepaid pension cost is the cumulative employer contribution in excess of the accrued net pension cost. The accrued pension cost is the pension cost in excess of the employer contribution. The AML is the funding shortfall above the accrued pension cost (net of the prepaid amount) for severely underfunded plans. When AML occurs, an intangible asset, a charge to book equity (after tax) and a deferred tax adjustment is created. Book (Market) D/A is the ratio between long term debt and the book (market) value of assets. Long term debt is calculated as the amount of debt obligations due more than one year in the future plus the current portion of the long term debt. We calculate the market value of assets as book assets minus book equity plus market equity. Book (Market) $\mathrm{D} /(\mathrm{D}+\mathrm{E})$ is long term debt divided by long term debt plus book (market) value of equity.

Reported Balance Sheet

(\$billion)

Reported assets (in \$ billions)

Less Prepaid Cost

Less intangible asset

Plus pension plan asset

Adjusted assets

Reported Liabilities (in \$ billions)

Less Accrued Pension Cost

Plus AML tax deferment adjustment

Plus pension liability Adjusted liabilities

Net Worth

Long Term Debt

Market Value of Equity
$\$ 324.00$

Consolidated Balance Sheet

(\$billion)

$-\$ 7.50$

$-\$ 6.20$

$\$ 73.70$

$\$ 384.00$

$\$ 303.50$

$-\$ 10.80$

$\$ 5.80$

$\$ 86.30$

$\$ 384.80$

$\$ 20.50$

$\$ 126.71$

$\$ 27.17$
$-\$ 0.80$

$\$ 213.01$

$\$ 27.17$
Netted Balance Sheet

(\$billion)

$-\$ 6.20$

$\$ 310.30$

$-\$ 10.80$

$\$ 5.80$

$\$ 12.60$

$\$ 311.10$

$-\$ 0.80$

$\$ 139.31$

$\$ 27.17$

Leverage ratios

\begin{tabular}{|c|c|c|c|}
\hline Book D/A & 0.39 & 0.55 & 0.46 \\
\hline Market D/A & 0.38 & 0.52 & 0.42 \\
\hline Book D/(D+E) & 0.86 & 1.00 & 1.01 \\
\hline Market D/(D+E) & 0.82 & 0.89 & 0.84 \\
\hline
\end{tabular}


Table 2

\section{Sample characteristics of pension sponsors versus non-sponsors}

This table partitions the sample into pension sponsors and non-sponsors. Book (Market) D/A is ratio between long term debt and the book (market) value of assets. Long term debt is calculated as the amount of long term debt plus the current portion of the long term debt. We calculate the market value of assets as book assets minus book equity plus market equity. Book (Market) $\mathrm{D} /(\mathrm{D}+\mathrm{E})$ is long term debt divided by long term debt plus book (market) value of equity. MTR $\mathrm{NONE}_{\mathrm{N}}$ is the marginal tax rate before interest or pension contributions. MTR $_{\mathrm{INT}}$ is the marginal tax rate after the interest expense deduction. $\mathrm{MTR}_{\mathrm{ALL}}$ is the marginal tax rate after both interest expense and pension contribution deductions. $\mathrm{KINK}_{\mathrm{INT}}$ is calculated based on the interest on debt and represents the proportion by which interest can be increased before the marginal tax benefit function becomes downward sloping. $\mathrm{KINK}_{\mathrm{ALL}}$ is the kink calculated based on both interest deductions and pension contributions. ASSETS are book assets. MB is the ratio between total debt plus market value of equity, and book assets. ROA is the operating income before depreciation divided by book assets. ROA VOL is the standard deviation of the historical operating income over the prior 10 years. COLLATERAL is net PPE divided by book assets. ZSCORE is defined as $3.3 *$ Pre-Tax Income + Sales $+1.4 *$ Retained earnings $+1.2 *$ (current assets-current liabilities) / Book assets. OENEG is a dummy equal to 1 if the book equity is negative. DIVIDEND PAYER is a dummy equal to 1 if the company paid common dividends in the prior year. IND MED LEV is the industry median book leverage. Industry is defined at the 4 digit SIC level. RATING is the S\&P Long Term Issuer credit rating ( 1 for the lowest rated and 19 for the highest rated). ***,**,* denote significance at the $0.1 \%$, $1 \%$ and $5 \%$ levels.

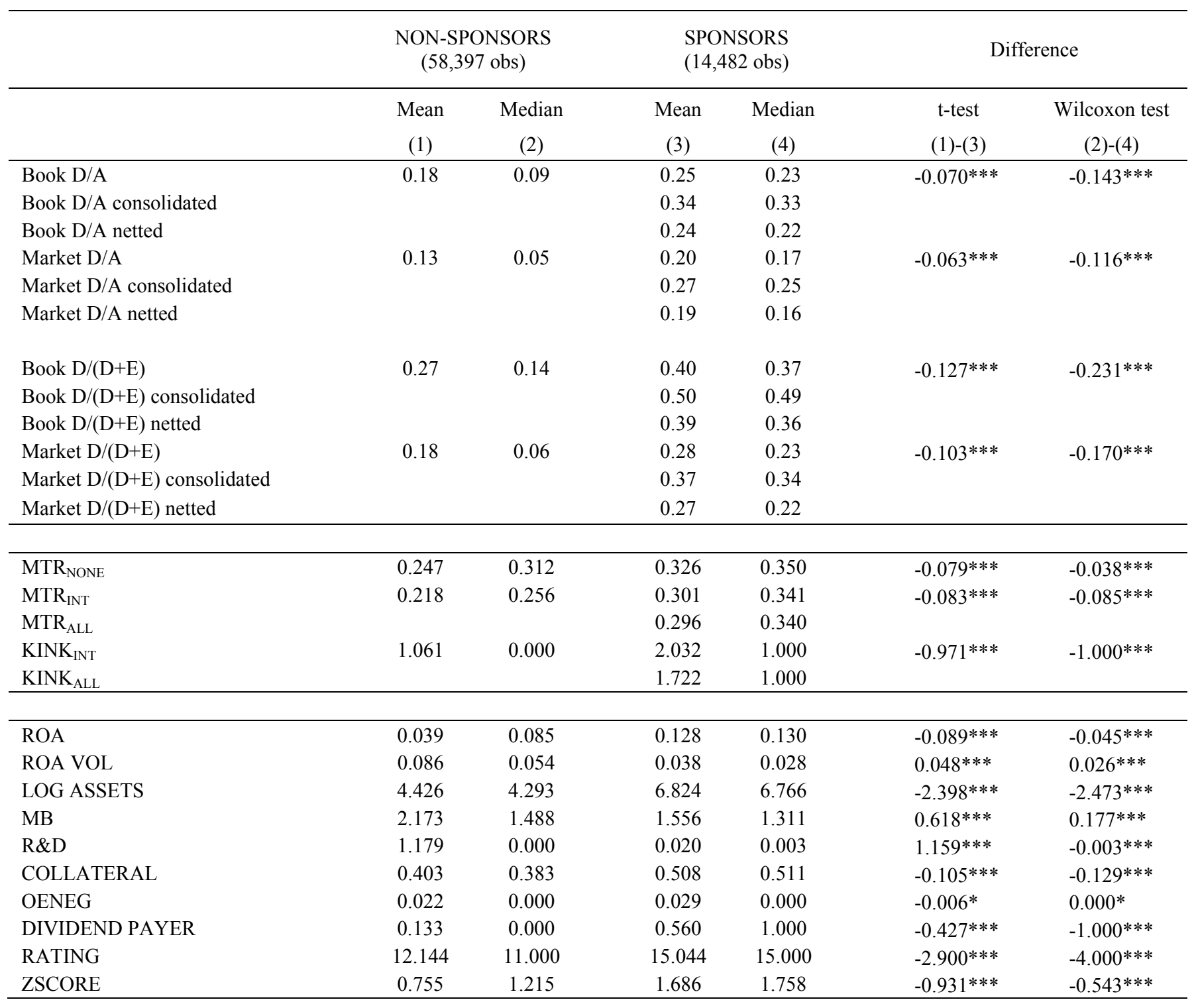


Table 3

Tax benefits of debt

This table reports the tax benefits from interest expense and pension contributions. The total tax benefits from consolidated debt (including pensions) is equal to the area under each firm's gross tax benefit function up to the actual aggregate interest expense. The aggregate (consolidated) interest expense is calculated as the sum of the regular interest expense and the pension contribution. Tax benefits from debt (excluding pensions) are calculated ignoring the tax deductibility of the pension contribution. The present value (PV) of tax benefits from current and future deductions is calculated under the assumption that tax shields are perpetual, using Moody's average bond yield as a discount rate. MV represents the market value of the firm and TA represents its book value of assets. The kink is the amount of interest where the marginal tax benefit function becomes downward sloping, expressed as a percentage of actual aggregate interest deductions.

\begin{tabular}{|c|c|c|c|c|c|c|c|c|}
\hline year & $\begin{array}{l}\text { No. of } \\
\text { firms }\end{array}$ & $\begin{array}{l}\text { Consolidated } \\
\text { interest /Interest } \\
\text { expense }\end{array}$ & $\begin{array}{c}\text { Tax benefits (with } \\
\text { pensions) / Tax } \\
\text { benefits (without } \\
\text { pensions) }\end{array}$ & $\begin{array}{c}\text { PV of Tax } \\
\text { benefits (without } \\
\text { pensions)/TA }\end{array}$ & $\begin{array}{l}\text { PV of Tax } \\
\text { benefits with } \\
\text { pensions/TA }\end{array}$ & $\begin{array}{c}\text { PV of Tax } \\
\text { benefits without } \\
\text { pensions/MV }\end{array}$ & $\begin{array}{c}\text { PV of Tax } \\
\text { benefits with } \\
\text { pensions /MV }\end{array}$ & $\begin{array}{l}\text { Change in kink } \\
\text { due to pensions }\end{array}$ \\
\hline 1991 & 1,107 & 1.326 & 1.225 & 0.131 & 0.147 & 0.108 & 0.120 & 0.200 \\
\hline 1992 & 1,136 & 1.500 & 1.241 & 0.129 & 0.145 & 0.101 & 0.113 & 0.240 \\
\hline 1993 & 1,277 & 1.439 & 1.231 & 0.132 & 0.148 & 0.097 & 0.109 & 0.243 \\
\hline 1994 & 1,303 & 1.612 & 1.342 & 0.120 & 0.142 & 0.093 & 0.109 & 0.284 \\
\hline 1995 & 1,319 & 1.489 & 1.292 & 0.130 & 0.149 & 0.098 & 0.112 & 0.306 \\
\hline 1996 & 1,350 & 1.696 & 1.403 & 0.128 & 0.154 & 0.094 & 0.112 & 0.361 \\
\hline 1997 & 1,342 & 1.532 & 1.288 & 0.127 & 0.147 & 0.087 & 0.101 & 0.339 \\
\hline 1998 & 1,265 & 1.505 & 1.289 & 0.137 & 0.158 & 0.103 & 0.118 & 0.305 \\
\hline 1999 & 1,219 & 1.517 & 1.273 & 0.130 & 0.148 & 0.103 & 0.116 & 0.321 \\
\hline 2000 & 1,195 & 1.372 & 1.236 & 0.132 & 0.148 & 0.111 & 0.123 & 0.322 \\
\hline 2001 & 1,194 & 1.477 & 1.269 & 0.128 & 0.145 & 0.102 & 0.113 & 0.337 \\
\hline 2002 & 1,182 & 1.714 & 1.371 & 0.122 & 0.146 & 0.101 & 0.119 & 0.389 \\
\hline 2003 & 1,044 & 2.070 & 1.545 & 0.121 & 0.158 & 0.089 & 0.113 & 0.596 \\
\hline Mean & & 1.556 & 1.307 & 0.128 & 0.149 & 0.099 & 0.114 & 0.324 \\
\hline Median & & 1.086 & 1.058 & 0.113 & 0.132 & 0.079 & 0.094 & 0.000 \\
\hline Firm-year obs. & 15,933 & 15,933 & 15,867 & 15,933 & 15,933 & 15,933 & 15,933 & 15,933 \\
\hline Overall STD & & 1.858 & 1.039 & 0.086 & 0.093 & 0.077 & 0.083 & 0.670 \\
\hline Between -firm STD & & 1.236 & 0.734 & 0.083 & 0.085 & 0.072 & 0.075 & 0.449 \\
\hline Within -firm STD & & 1.481 & 0.819 & 0.045 & 0.054 & 0.041 & 0.048 & 0.498 \\
\hline
\end{tabular}




\section{Table 4}

\section{Pension plan size, marginal tax rates and change in debt conservatism}

The table reports the effect of the relative size of the pension plan on debt conservatism once the pension plan is integrated in the calculation of MTRs. PA/TA is the relative size of pension assets to book assets. MTR $\mathrm{INT}_{\mathrm{IN}}$ is the marginal tax rate after the interest expense is deducted. MTR $\mathrm{ALL}_{\mathrm{L}}$ is the marginal tax rate after both interest expense and pension contribution deductions. Tax benefits without pensions are calculated without accounting for the tax deductibility of the pension contribution. $\mathrm{KINK}_{\mathrm{INT}}$ is calculated based on the interest on debt only and represents the proportion by which interest can be increased before the marginal tax benefit function becomes downward sloping. $\mathrm{KINK}_{\mathrm{ALL}}$ is the kink calculated based on both interest expense on debt and pension contributions. The change in debt conservatism is calculated as the difference between $\left(\mathrm{KINK}_{\mathrm{ALL}}-1\right)$ and $\left(\mathrm{KINK}_{\mathrm{INT}}-1\right)$. The percentage change in debt conservatism is defined as the change in debt conservatism divided by $\left(\mathrm{KINK}_{\mathrm{INT}}-1\right)$.

\begin{tabular}{|c|c|c|c|c|c|c|c|c|c|c|c|}
\hline $\begin{array}{c}\mathrm{PA} / \mathrm{TA} \\
( \\
\text { Deciles })\end{array}$ & Obs. & $\mathrm{MTR}_{\mathrm{INT}}$ & $\mathrm{MTR}_{\mathrm{ALL}}$ & Diff. & $\begin{array}{c}\text { Tax } \\
\text { benefits } \\
\text { (without } \\
\text { pensions) }\end{array}$ & $\begin{array}{l}\text { Tax } \\
\text { benefits } \\
\text { (with } \\
\text { pensions) }\end{array}$ & Diff. & $\mathrm{KINK}_{\mathrm{INT}}$ & $\mathrm{KINK}_{\mathrm{ALL}}$ & $\begin{array}{l}\text { Change in debt } \\
\text { conservatism }\end{array}$ & $\begin{array}{l}\text { Percentage } \\
\text { change in debt } \\
\text { conservatism }\end{array}$ \\
\hline 1 & 1576 & 0.288 & 0.287 & -0.001 & 32.29 & 36.44 & 4.15 & 1.83 & 1.79 & -0.04 & -0.04 \\
\hline 2 & 1575 & 0.297 & 0.295 & -0.001 & 32.20 & 40.48 & 8.27 & 1.72 & 1.53 & -0.19 & -0.26 \\
\hline 3 & 1576 & 0.297 & 0.294 & -0.003 & 35.16 & 45.78 & 10.61 & 1.90 & 1.69 & -0.21 & -0.24 \\
\hline 4 & 1575 & 0.301 & 0.299 & -0.003 & 43.79 & 51.63 & 7.84 & 1.97 & 1.72 & -0.25 & -0.26 \\
\hline 5 & 1576 & 0.303 & 0.299 & -0.004 & 51.31 & 63.17 & 11.85 & 2.08 & 1.77 & -0.31 & -0.29 \\
\hline 6 & 1575 & 0.307 & 0.303 & -0.004 & 51.64 & 62.83 & 11.20 & 2.20 & 1.85 & -0.36 & -0.30 \\
\hline 7 & 1576 & 0.309 & 0.304 & -0.005 & 68.53 & 87.70 & 19.17 & 2.50 & 2.06 & -0.44 & -0.29 \\
\hline 8 & 1575 & 0.306 & 0.299 & -0.006 & 55.40 & 73.43 & 18.03 & 2.37 & 1.94 & -0.43 & -0.31 \\
\hline 9 & 1576 & 0.301 & 0.293 & -0.008 & 70.87 & 96.97 & 26.10 & 2.17 & 1.77 & -0.41 & -0.35 \\
\hline 10 & 1575 & 0.281 & 0.268 & -0.013 & 53.81 & 76.09 & 22.28 & 1.47 & 1.13 & -0.34 & -0.72 \\
\hline
\end{tabular}




\section{Table 5}

\section{Selectivity model: Estimation of pension liabilities}

This table reports the results of the joint MLE estimation of the pension choice and size, within the framework of a self selection model. Pension choice is 1 if the firm sponsors a defined benefit plan and 0 otherwise. Pension size is measured by the projected benefit obligation and it is normalized by consolidated assets. ASSETS are consolidated book assets. MB is the ratio between total debt plus market equity and book assets. ROA is the operating income before depreciation divided by book assets. ROA VOL is the standard deviation of the historical operating income based on the prior 10 years. COLLATERAL is net PPE divided by book assets. ZSCORE is defined as 3.3*Pre-Tax Income + Sales $+1.4 *$ Retained earnings $+1.2 *$ (current assets-current liabilities) / Book assets. OENEG is a dummy equal to 1 if book equity is negative. IND MED LEV is the industry median book leverage. Industry is defined at the 4 digit SIC level. UNIONIZATION is the percentage of employed workers in an industry represented by a union as reported in the Current Population Survey of the Department of Labor. TENURE is the median employee tenure by industry. PLAN AGE is equal to the number of years the defined benefit plans' assets and liabilities are reported in the footnotes of the annual reports. Robust t-statistics are reported in parenthesis. We use $* * *, * *, *$ to denote significance at the $0.1 \%, 1 \%$ and $5 \%$ levels.

\begin{tabular}{|c|c|c|}
\hline & $\begin{array}{c}\text { Pension choice } \\
\text { (1) }\end{array}$ & $\begin{array}{c}\text { Pension size } \\
\text { (2) }\end{array}$ \\
\hline LOG ASSETS & $\begin{array}{c}0.375 * * * \\
(89.78)\end{array}$ & $\begin{array}{l}-0.000 \\
(-0.03)\end{array}$ \\
\hline MB & $\begin{array}{c}-0.152 * * * \\
(-23.47)\end{array}$ & $\begin{array}{l}-0.002 \\
(-0.91)\end{array}$ \\
\hline ROA VOL & $\begin{array}{c}0.000 * * * \\
(11.57)\end{array}$ & $\begin{array}{c}-0.000 * * * \\
(-3.48)\end{array}$ \\
\hline ROA & $\begin{array}{c}0.949 * * * \\
(15.00)\end{array}$ & $\begin{array}{c}-0.265^{* * *} \\
(-14.49)\end{array}$ \\
\hline COLLATERAL & $\begin{array}{c}0.500 * * * \\
(16.16)\end{array}$ & $\begin{array}{l}-0.010 \\
(-1.56)\end{array}$ \\
\hline ZSCORE & & $\begin{array}{c}0.009 * * * \\
(8.98)\end{array}$ \\
\hline OENEG & & $\begin{array}{c}0.099 * * * \\
(20.14)\end{array}$ \\
\hline IND MEDIAN LEV. & & $\begin{array}{c}-0.153 * * * \\
(-13.87)\end{array}$ \\
\hline UNIONIZATION & $\begin{array}{c}0.016^{* * *} \\
(9.86)\end{array}$ & \\
\hline TENURE & $\begin{array}{c}0.027 * * * \\
(4.32)\end{array}$ & $\begin{array}{c}0.008 * * * \\
(10.17)\end{array}$ \\
\hline PLAN AGE & & $\begin{array}{c}0.006 * * * \\
(27.32)\end{array}$ \\
\hline Constant & $\begin{array}{c}1.496 * * * \\
(30.44) \\
\end{array}$ & $\begin{array}{c}0.102 * * * \\
(14.60) \\
\end{array}$ \\
\hline Year fixed effects & Yes & Yes \\
\hline Industry fixed effects & Yes & \\
\hline Number of observations & 55,521 & 11,430 \\
\hline Pseudo $\mathrm{R}^{2}$ (probit) & $30 \%$ & \\
\hline \multicolumn{3}{|l|}{ Diagnostic tests: } \\
\hline $\begin{array}{l}\text { Wald test: all coefficient }=0 \quad(\chi 2) \\
\text { Heckman's } \lambda \\
\text { Likelihood ratio test of independent equations }(\rho=0)(\chi 2)\end{array}$ & $\begin{array}{c}2031.87 * * * \\
-0.030 * * \\
5.18 * * *\end{array}$ & \\
\hline
\end{tabular}




\section{Table 6}

\section{The relationship between pension liabilities and financial debt}

Regression estimates for consolidated book leverage. The first column presents the parameter estimates of the two-step treatment effects model. The t-statistics reported in parentheses are calculated based on bootstrapped standard errors. The second column presents parameter estimates from a pooled OLS regression. Robust t-statistics are reported in parenthesis. The third column presents parameter estimates from a pooled OLS regression with firm fixed effects. The t-statistics reported in parenthesis are robust to heteroskedasticity and within firm serial correlation. AR(1) is the estimated first order serial correlation coefficient. DBP is set to 1 if the firm sponsors a defined benefit plan and 0 otherwise. In the treatment effects model specification, PENSION is the predicted pension size. In the pooled OLS and Firm FE specifications, PENSION is the projected benefit obligation normalized by consolidated assets. ASSETS are consolidated book assets. MB is the ratio between total debt plus market equity, and book assets. MTR $_{\mathrm{NONE}}$ is the simulated marginal tax rate before any interest or pension contributions are deducted. ROA VOL is the standard deviation of the historical operating income based on the 10 prior years. COLLATERAL is net PPE divided by book assets. ZSCORE is defined as $3.3 *$ Pre-Tax Income + Sales $+1.4 *$ Retained earnings $+1.2 *$ (current assets-current liabilities) / Book assets. OENEG is a dummy equal to 1 if the book equity is negative. IND MED LEV is the industry median book leverage. Industry is defined at the 4 digit SIC level. We use $* * *, * *, *$ to denote significance at the $0.1 \%, 1 \%$ and $5 \%$ levels.

\begin{tabular}{|c|c|c|c|}
\hline & $\begin{array}{c}\text { Treatment effects } \\
(1)\end{array}$ & $\begin{array}{c}\text { Pooled OLS } \\
(2) \\
\end{array}$ & $\begin{array}{c}\text { Firm FE } \\
(3) \\
\end{array}$ \\
\hline DBP & $\begin{array}{l}0.014 \\
(1.60)\end{array}$ & $\begin{array}{c}0.022 * * * \\
(4.03)\end{array}$ & $\begin{array}{c}0.021 * * * \\
(3.97)\end{array}$ \\
\hline DBP*PENSION & $\begin{array}{c}-0.360 * * * \\
(-6.54)\end{array}$ & $\begin{array}{c}-0.394 * * * \\
(-18.40)\end{array}$ & $\begin{array}{c}-0.252 * * * \\
(-9.58)\end{array}$ \\
\hline MTR $_{\text {NONE }}$ & $\begin{array}{c}0.045^{* * *} \\
(5.81)\end{array}$ & $\begin{array}{c}0.056^{* * *} \\
(5.27)\end{array}$ & $\begin{array}{l}0.006 \\
(1.14)\end{array}$ \\
\hline LOG ASSETS & $\begin{array}{c}0.019 * * * \\
(45.21)\end{array}$ & $\begin{array}{c}0.019 * * * \\
(19.36)\end{array}$ & $\begin{array}{c}0.020 * * * \\
(12.33)\end{array}$ \\
\hline MB & $\begin{array}{c}-0.012 * * * \\
(-22.43)\end{array}$ & $\begin{array}{c}-0.012 * * * \\
(-21.35)\end{array}$ & $\begin{array}{c}-0.002 * * * \\
(-5.62)\end{array}$ \\
\hline ZSCORE & $\begin{array}{c}-0.007 * * * \\
(-22.64)\end{array}$ & $\begin{array}{c}-0.007 * * * \\
(-15.02)\end{array}$ & $\begin{array}{c}-0.002 * * * \\
(-4.61)\end{array}$ \\
\hline OENEG & $\begin{array}{c}0.195 * * * \\
(28.56)\end{array}$ & $\begin{array}{c}0.196 * * * \\
(19.89)\end{array}$ & $\begin{array}{l}-0.003 \\
(-0.93)\end{array}$ \\
\hline ROA VOL & $\begin{array}{c}-0.000 * * * \\
(-8.02)\end{array}$ & $\begin{array}{c}-0.000 * * * \\
(-5.36)\end{array}$ & $\begin{array}{l}-0.000 \\
(-0.53)\end{array}$ \\
\hline COLLATERAL & $\begin{array}{c}0.116^{* * *} \\
(30.12)\end{array}$ & $\begin{array}{c}0.116^{* * *} \\
(15.46)\end{array}$ & $\begin{array}{c}0.057 * * * \\
(8.62)\end{array}$ \\
\hline IND MEDIAN LEV. & $\begin{array}{c}0.496^{* * * *} \\
(48.9)\end{array}$ & $\begin{array}{c}0.494 * * * \\
(25.53)\end{array}$ & $\begin{array}{c}0.090 * * * \\
(3.82)\end{array}$ \\
\hline Constant & $\begin{array}{c}0.221 * * * \\
(37.40)\end{array}$ & $\begin{array}{c}0.220 * * * \\
(23.09)\end{array}$ & $\begin{array}{c}-0.031 * * * \\
(-4.47)\end{array}$ \\
\hline Year fixed effects & Yes & Yes & Yes \\
\hline $\begin{array}{l}\text { R-squared } \\
\operatorname{AR}(1)\end{array}$ & 0.242 & 0.24 & 0.499 \\
\hline Observations & 55,521 & 55,521 & 45,753 \\
\hline \multicolumn{4}{|l|}{ Diagnostic tests } \\
\hline Heckman's $\lambda$ & $0.002 * * *$ & & \\
\hline Underidentification test (LM statistic) $\quad\left(\chi^{2}\right)$ & $22,000 * * *$ & & \\
\hline Weak identification test (Stock and Yogo) (F test) & $19,004 * * *$ & & \\
\hline Overidentification test (Sargan statistic) $\left(\chi^{2}\right)$ & $13.546^{* * *}$ & & \\
\hline Exogeneity test $(\chi 2)$ & $27.561 * * *$ & & \\
\hline
\end{tabular}


Table 7

Variance decompositions

This table presents the variance decomposition for different specifications of consolidated book leverage for our sample of pension sponsors. The adjusted $\mathrm{R}^{2}$ is presented on the bottom row. The methodology follows Lemmon, Roberts and Zender (2008) and calculates the type III partial sum of squares for each effect in the model and then normalizes each estimate by the sum across effects. FIRM FE, YEAR FE and IND FE are firm fixed effects, year fixed effects, and industry fixed effects respectively. Industry is defined at the 4 digit SIC level. Consolidated book leverage has been defined in the text. PENSION is the projected benefit obligation. MTR $_{\text {NONE }}$ is the marginal tax rate before interest and pension contributions. $\mathrm{MB}$ is the ratio between total debt plus market equity, and book assets. ZSCORE is defined as 3.3*Pre-Tax Income + Sales $+1.4 *$ Retained earnings $+1.2 *$ (current assets-current liabilities) / Book assets. COLLATERAL is net PPE to book assets. OENEG is a dummy equal to 1 if the book equity is negative. ASSETS are book assets. ROA VOL is the standard deviation of the historical operating income, based on the prior 10 years. IND MED LEV is the industry median book leverage.

\begin{tabular}{|c|c|c|c|c|c|c|}
\hline & (1) & (2) & (3) & (4) & (5) & (6) \\
\hline FIRM FE & 1.00 & 0.99 & & 0.94 & & 0.93 \\
\hline YEAR FE & & 0.01 & 0.04 & 0.01 & 0.03 & 0.01 \\
\hline PENSION & & & & & 0.12 & 0.01 \\
\hline $\mathrm{MTR}_{\mathrm{NONE}}$ & & & 0.03 & 0.00 & 0.02 & 0.00 \\
\hline MB & & & 0.04 & 0.00 & 0.04 & 0.00 \\
\hline ZSCORE & & & 0.15 & 0.02 & 0.13 & 0.02 \\
\hline OENEG & & & 0.04 & 0.00 & 0.05 & 0.00 \\
\hline LOG ASSETS & & & 0.02 & 0.01 & 0.03 & 0.00 \\
\hline ROA VOL & & & 0.02 & 0.00 & 0.02 & 0.00 \\
\hline COLLATERAL & & & 0.03 & 0.00 & 0.02 & 0.00 \\
\hline IND MED LEV. & & & 0.01 & 0.00 & 0.00 & 0.00 \\
\hline IND FE & & & 0.63 & & 0.54 & \\
\hline $\operatorname{Adj} R^{2}$ & 0.69 & 0.70 & 0.42 & 0.74 & 0.47 & 0.75 \\
\hline
\end{tabular}

